\title{
رومانتيكية العاطفة والخيال فى شعر الغزل لعنترة بن شداد
}

Cahya Buana dan Desa Sari Rahmawati

cahya.buana@uinjkt.ac.id

Universitas Islam Negeri Syarif Hidayatullah Jakarta

\begin{abstract}
Abstrak
Antarah Ibn Abi Syaddād merupakan salah seorang Penyair masa Jahiliyah yang terkenal dengan puisi-puisi gazahya yang lahir akibat cintanya yang mendalam kepada Ablah anak Pamannya sendiri, namun tidak menyetujuinya. Puisi gazal termasuk puisi yang banyak diminati karena terkait dengan naluri dan pengalaman pribadi seseorang. Puisi gazal umumnya lahir dari perasaan yang jujur seorang penyair yang kemudian ia warnai dengan imaginasi dan diungkapkan dengan gaya bahasa yang indah. Penelitian ini bertujuan untuk mengetahui bagaimana emosi dan imajinasi dalam puisi gazal Antarah bin Syaddād yang diungkapkan pada kekasihnya Ablah binti Malik, pamannya. Untuk menganalisis kedua aspek tersebut, digunakan pendekatan romantisme. Dari hasil analisis diketahui bahwa romantisme emosi yang terdapat dalam puisi Antarah lahir dari self regarding emotion dan painful emotion. Adapun romantisme imajinasinya tampak pada interpreative imagination dan associative imagination yang digunakannya.
\end{abstract}

Kata kunci: Puisi Cinta; Romantisme; Emosi; Imajinasi

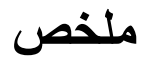

عنترة ابن أبي شداد شاعر من شعر اء العصر الجاهلي المشهور

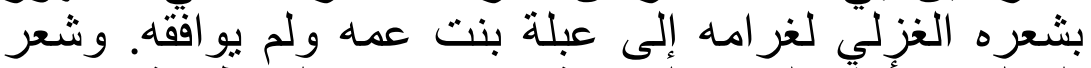

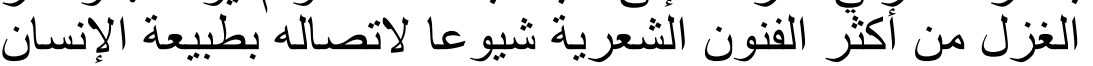

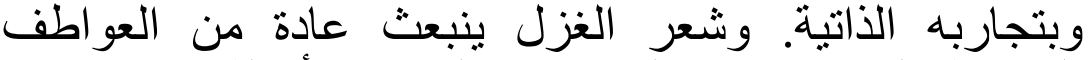

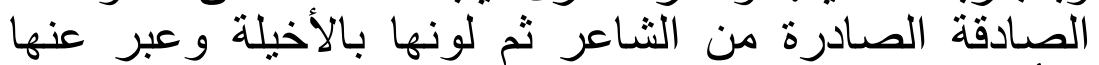

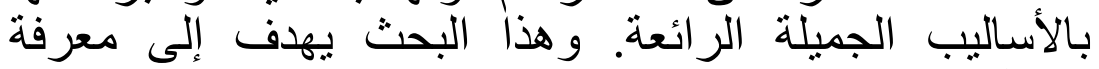

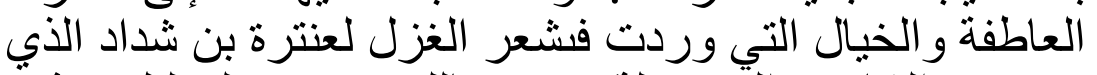

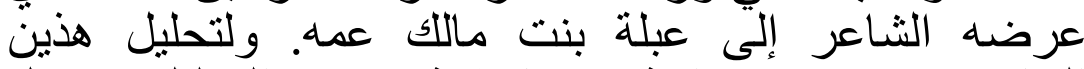

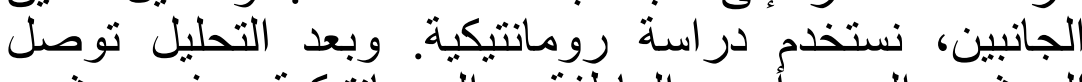

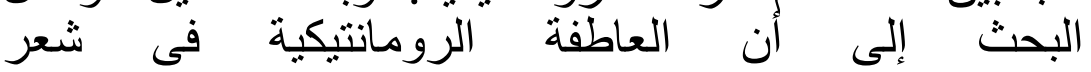


عنترةظهرتمنعو اطف الثاعر الثخصية و عو اطفه الأليمة. و أما الخيال الرومانتكى فى هذا الثعر فقد ظهرفي خياله البيانى

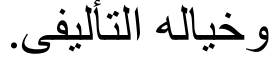
الكلمات المفتاحية: شعر الغزل، الرومانتيكية، العاطفة، الخيال.

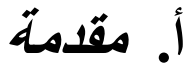

الرومانتيكية مذهب أدبي من أخطر ما عرفته الحياة الأدبية العالمية،

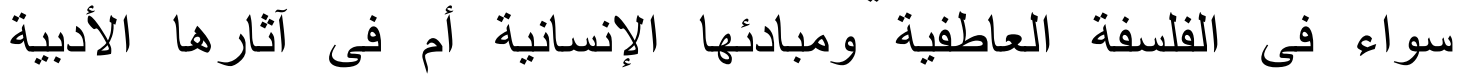

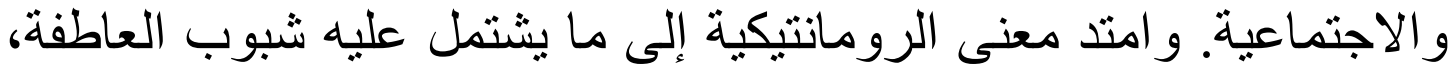

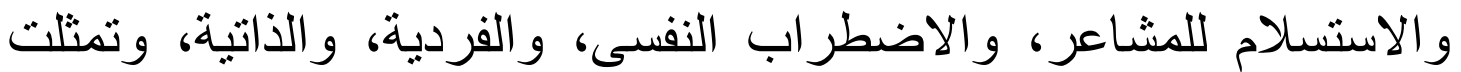

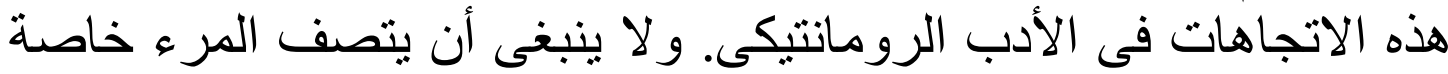

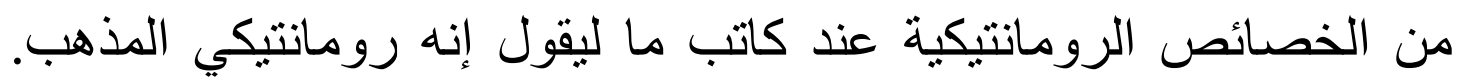

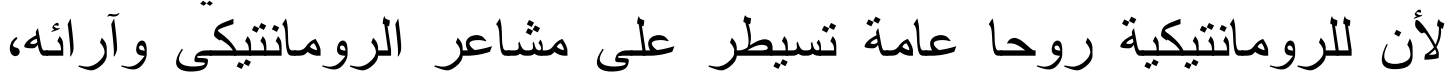

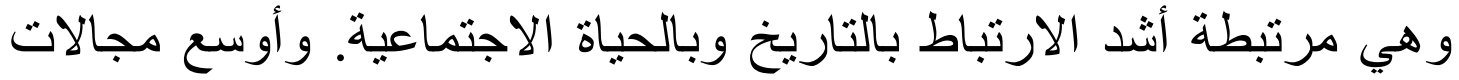

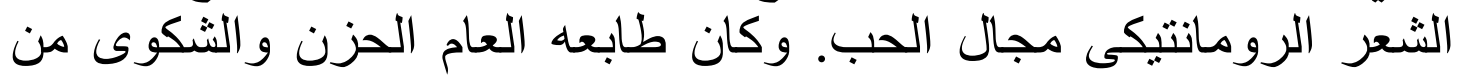

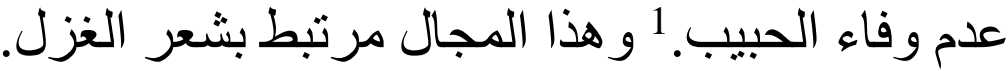

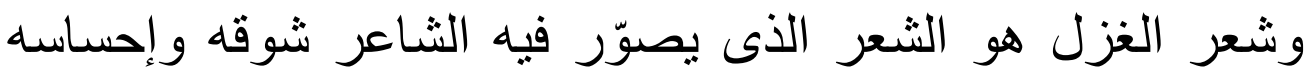

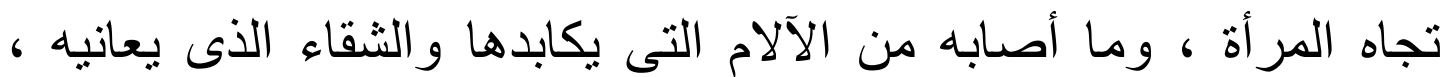

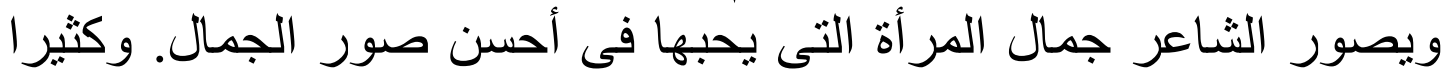

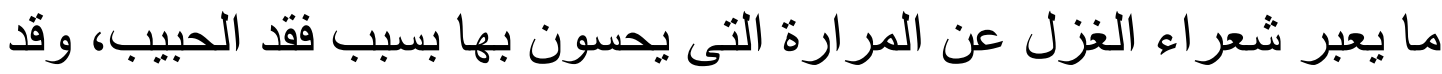

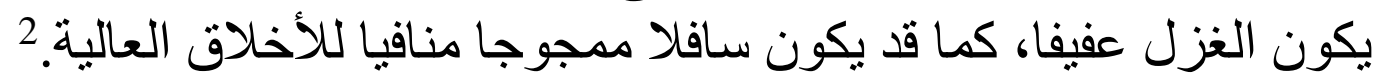

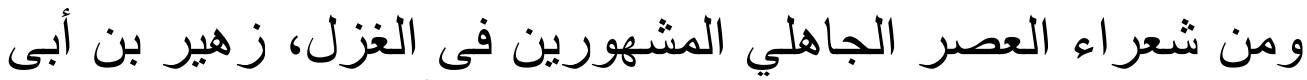

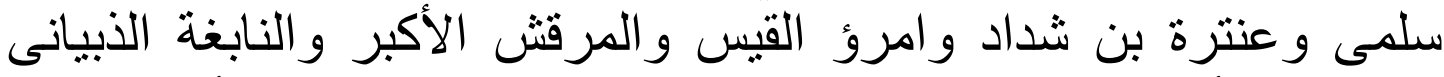
وطرفة والأعىى وعلقمة بن عبده.3ُوكان عنترة بن شداد هو أحد فرسان الأن

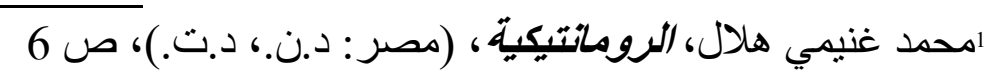

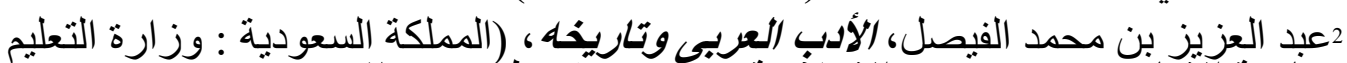

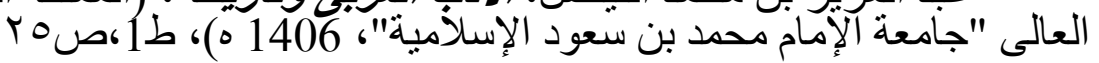

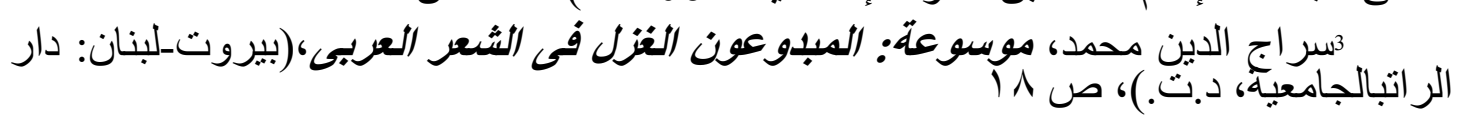


العرب المشهورين وأجوادهم المعروفين وأحد الأغربة الجاهليين. 4 وكان

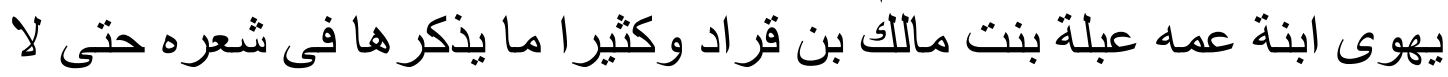

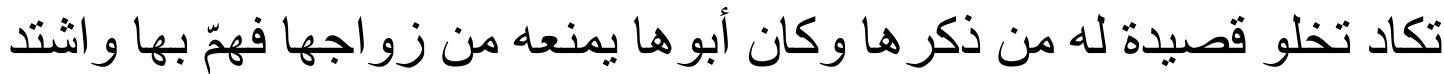

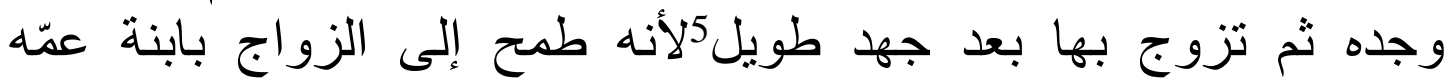

\section{ب. خلفية رومانتيكية عنترة بن شد/د}

لقد ذاق عنترة من الغرام أعنفه، فقد أحب أعظم الحب وأشده إبنة

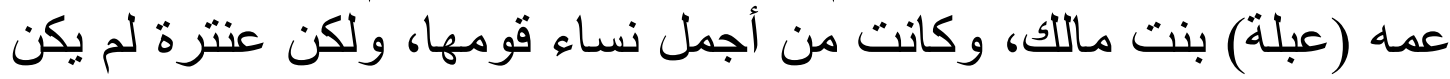

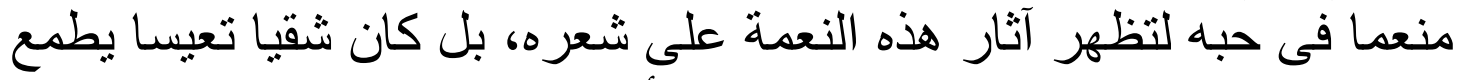

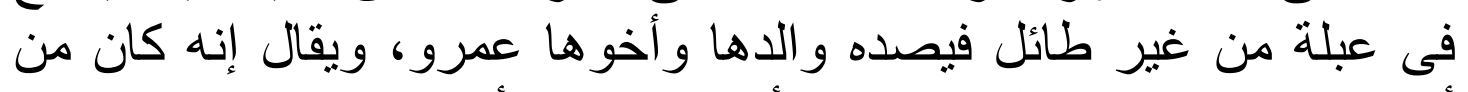

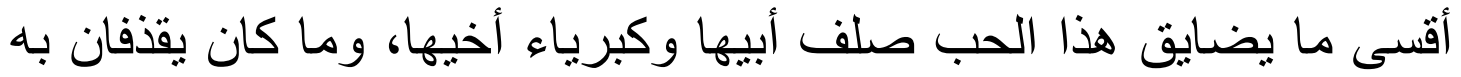

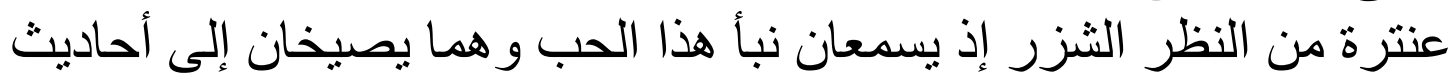

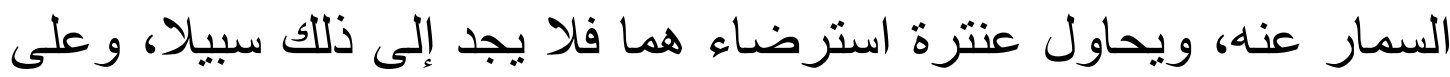

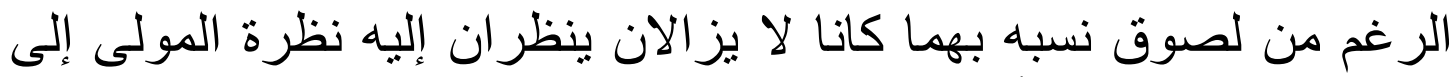

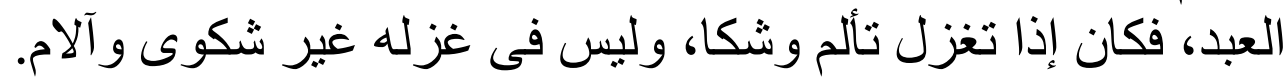

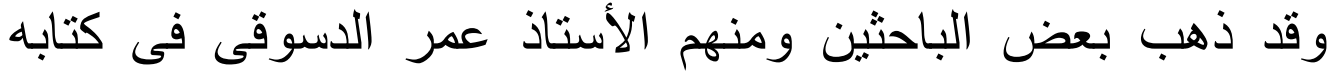

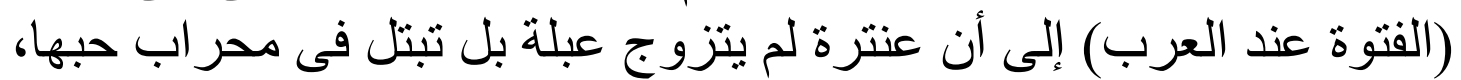

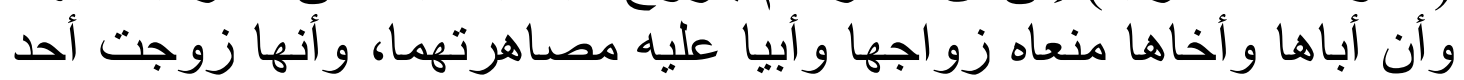

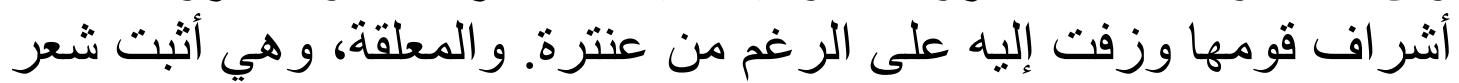

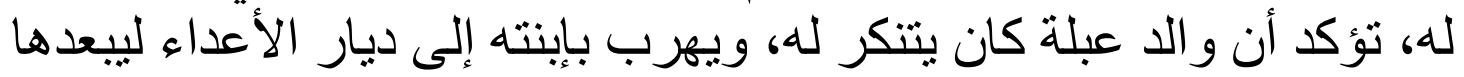

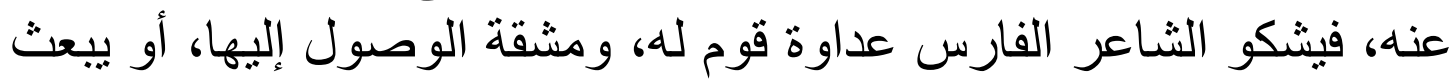
جاريته تتجسس فئكو لله أخبار ها.

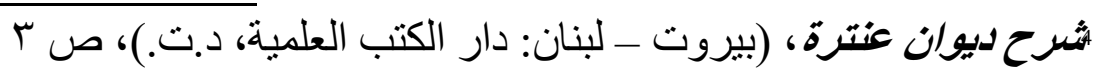

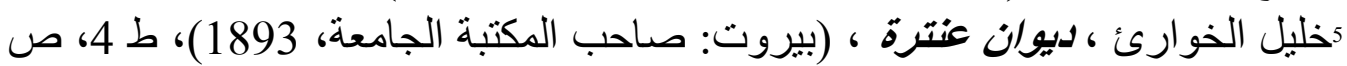

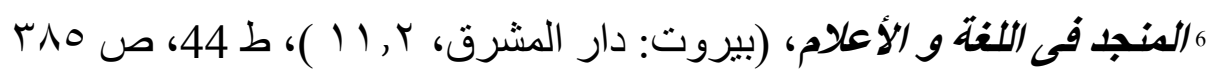

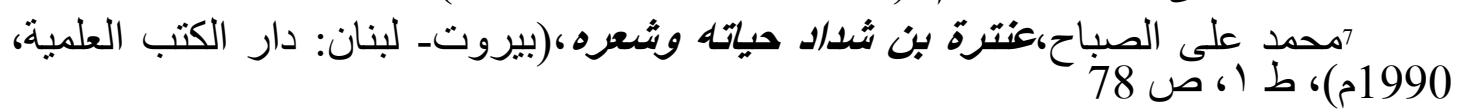




\section{ج. مغني الرومانتيكية}

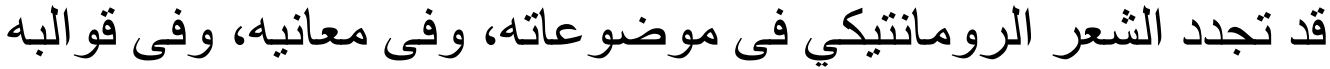

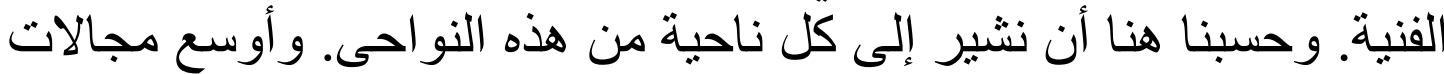

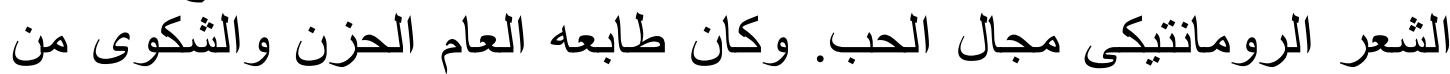

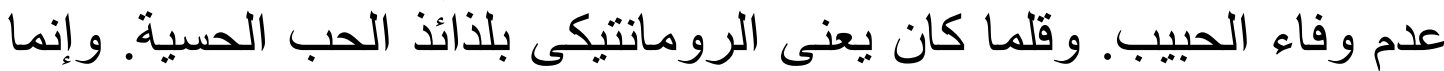
كان حبه عاطفيا حالما، يمتاز بأنه يضيق بالعقبات التى تعترض الته طريقها،

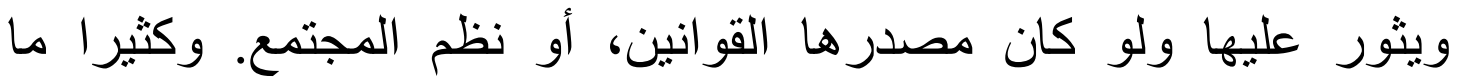

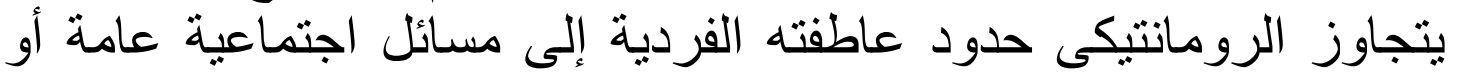

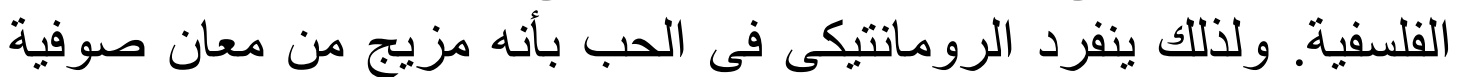

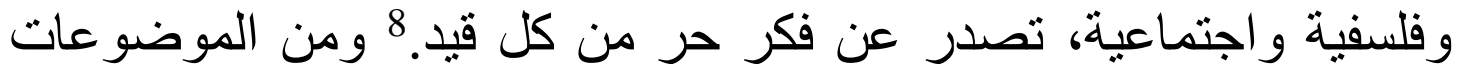

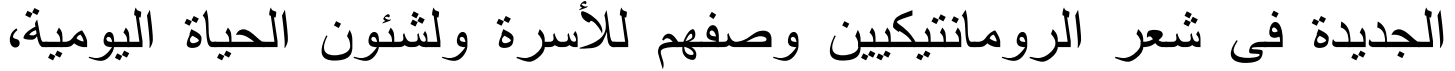

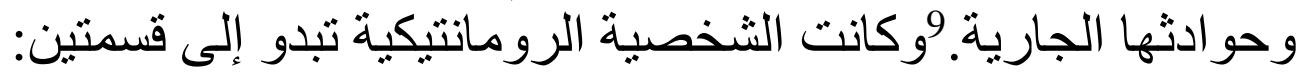

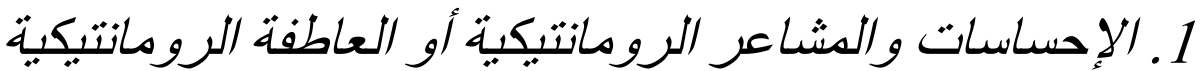

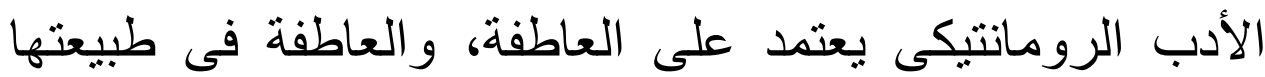

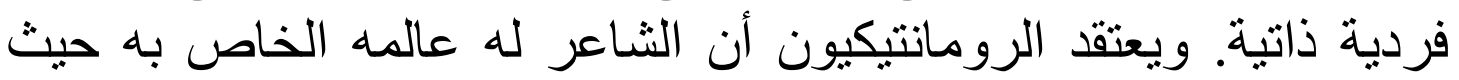

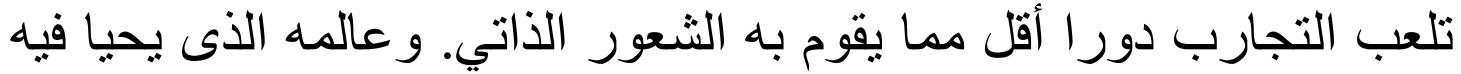
يفوق العالم الطبيعي. وهو فيه الآمر المسيطر. وكل ما هو هو فيه فيه عجيب

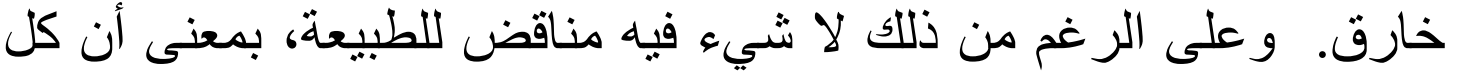
شيء فيه على وفق الإدراكات التى تتكون عادئ فئ فيه فئ الطبائع السحرية

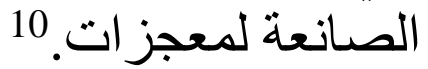

فالعاطفة هي التى تحدث عن شعور الكاتب وتثير شعور القارئ

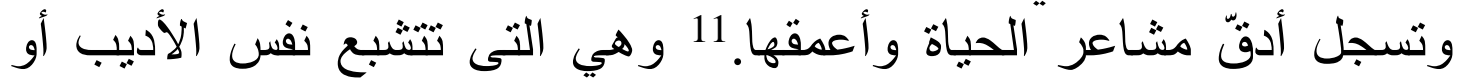

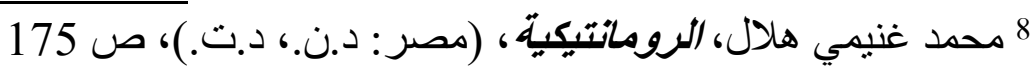

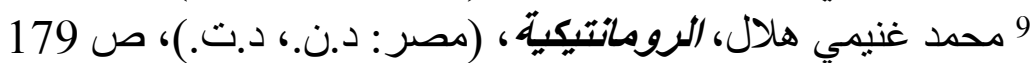

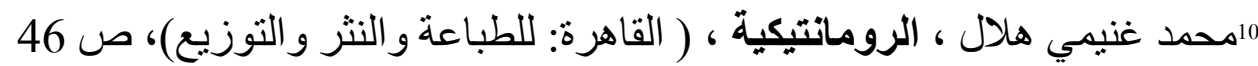
11أحمد أمين، النقل الأدبى، (القاهرة: مكتبة النهضة المصنية الطصرية، 1972)، ط4، ص 24 
الثشاعر من الحالة النفسية وتؤثر فيها تأثثرا قويا يدفعه إلى التعبير عن مشاعره.

\section{أنواع العاطفة:}

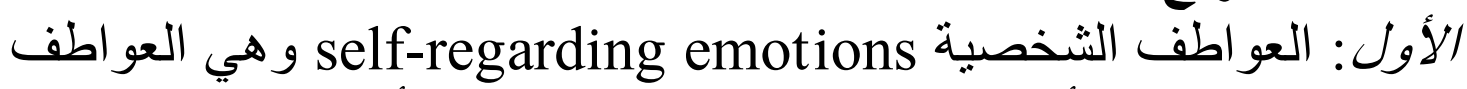

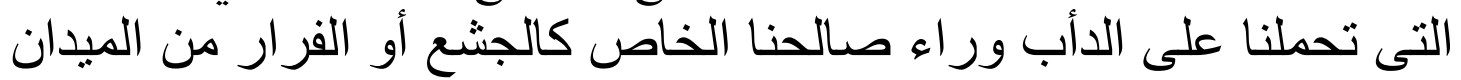

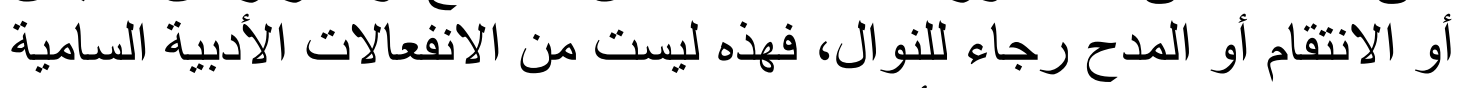

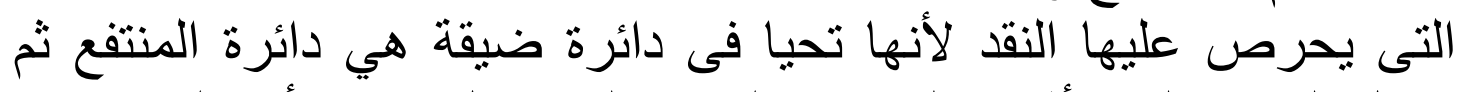

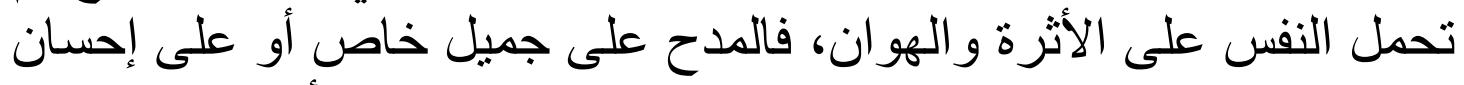

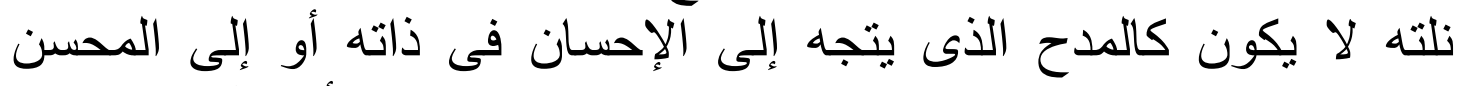

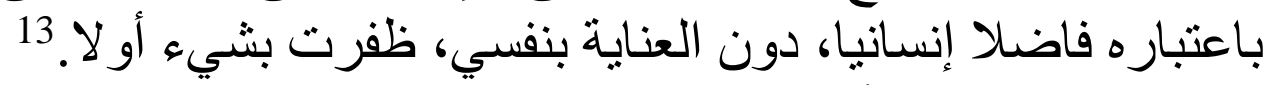

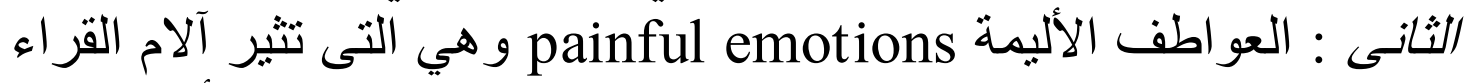

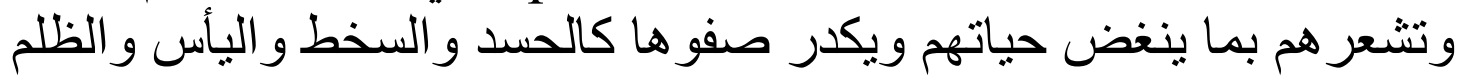

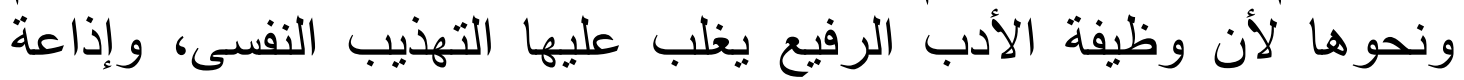

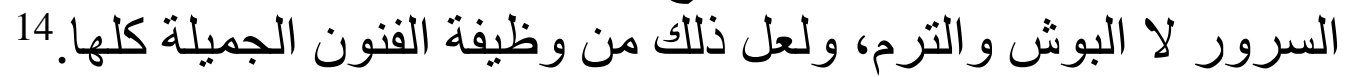

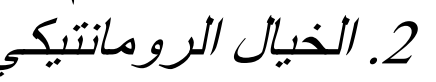

كانت نتيجة طبيعية لانطواء الرومانتيكي على نفسه وطغئي الريان

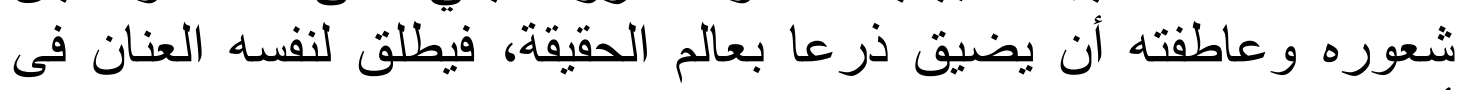

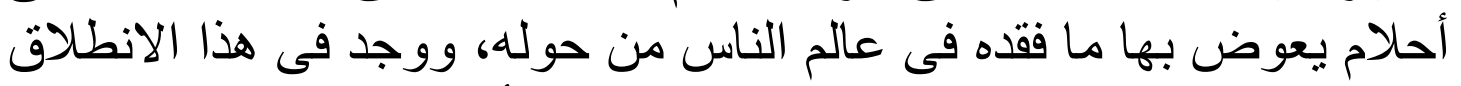

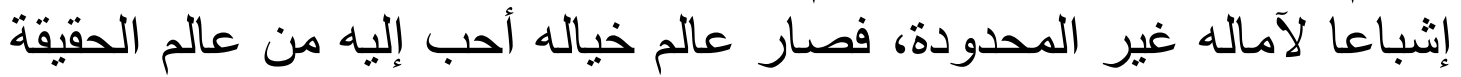

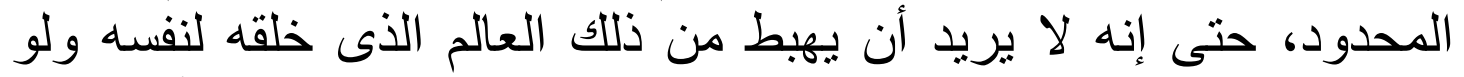

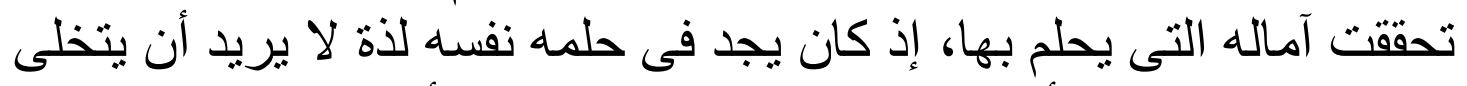
عنها. و لا عجب فى أن توحى هذه النزعة بالحزن، الأن الخيال فى اتجاهاته لانه

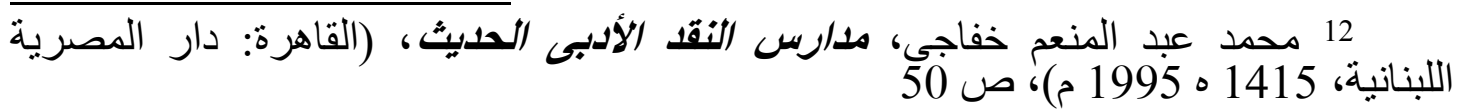

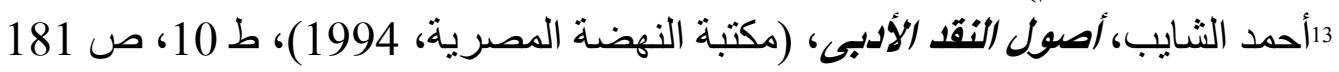

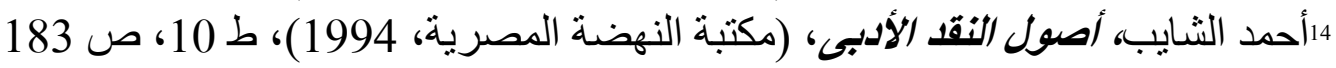


المختلفة استعاضة عما يريد الرومانتيكيون الحصول عليه حقيقة. ولكنه لا

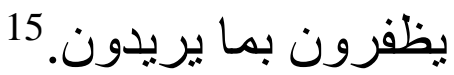

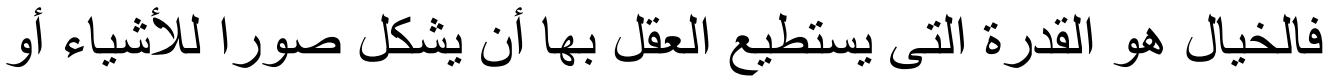

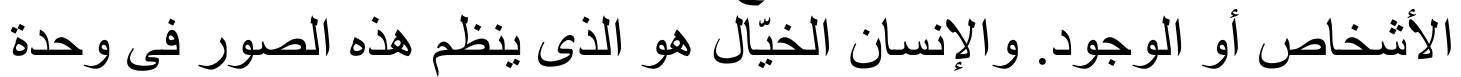

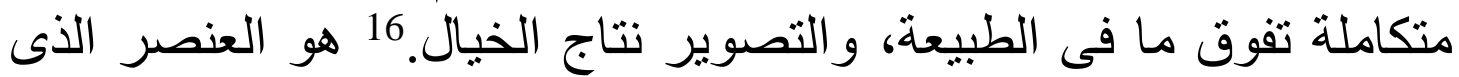

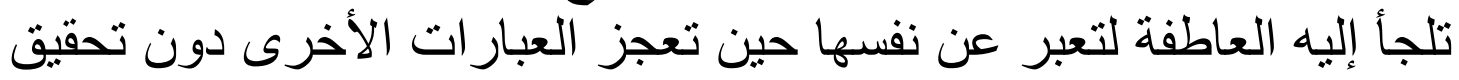
هذه الغاية الأدبية.

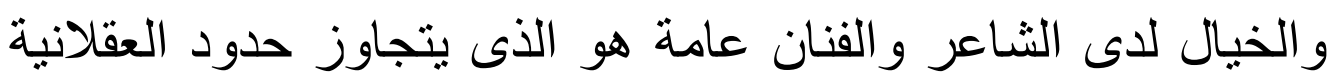

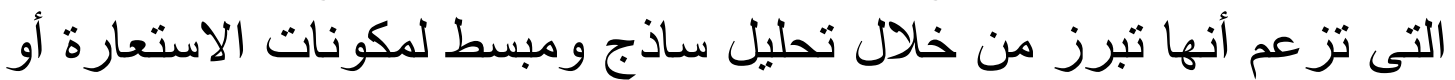

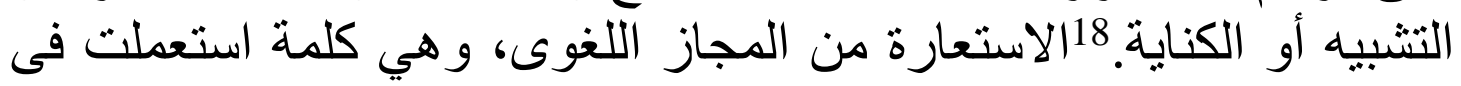

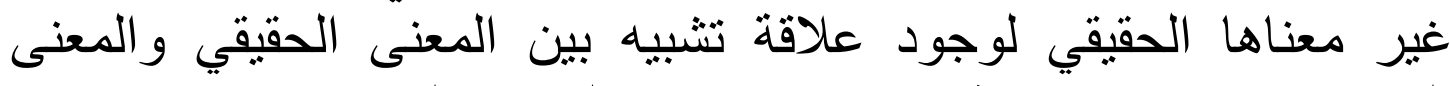

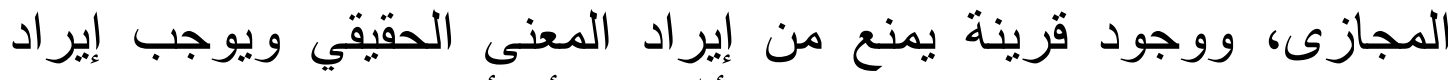

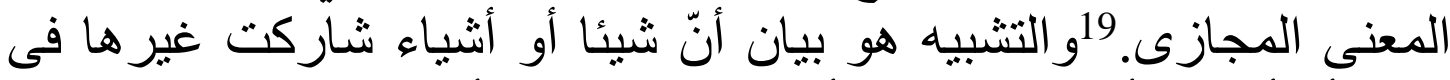

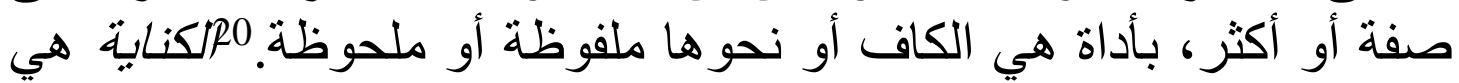

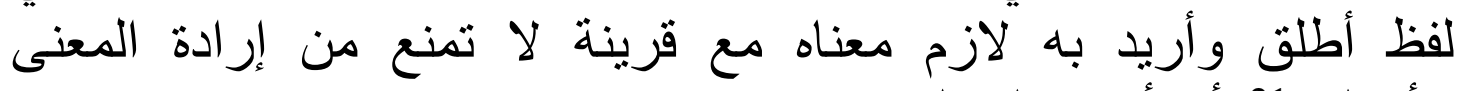

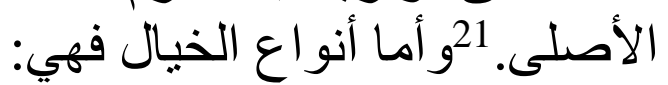

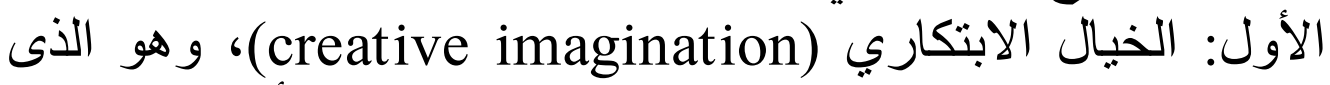

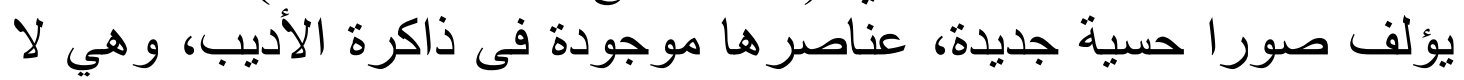

15 محمد غنيمي هلال ، الروماتتيكية ، ( القاهرة: للطباعة والنتر و التوزيع)، ص 64

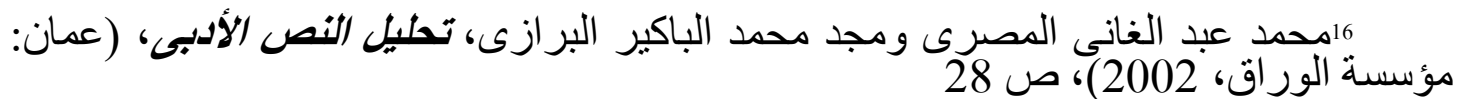
17 أحمد الثايب، أصول النقل الأدبى، (القاهرة: مكتبة النهضة المصرية، 1994)، ط 10،

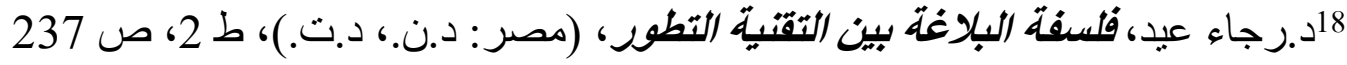

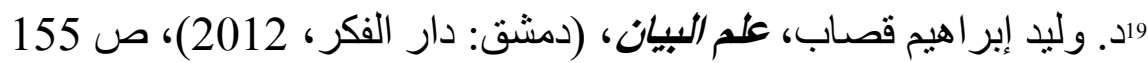

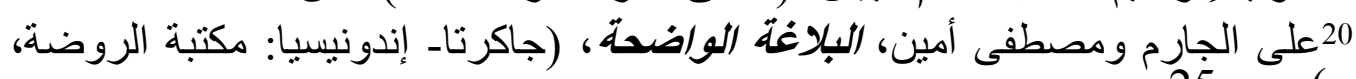
2007 م)، ص صن 25 المكتبة العصرية)، صد الهاثنمي، جواهر البلاغة فى المعاني والبيان والبليع، (صبد-بيروت: 
تقدم الواقع الخارجي كما هو في حدوده المادية، و إنما تقدمه على شئ شكل

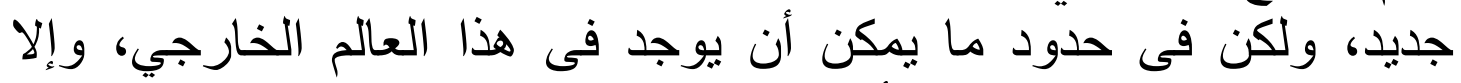

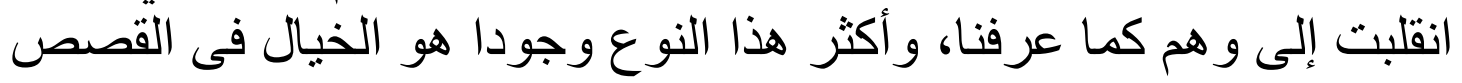

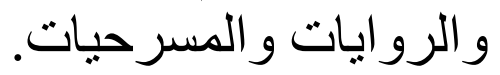

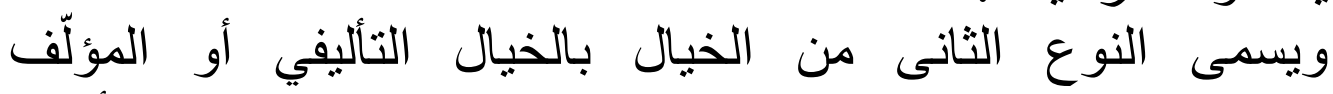
(associative imagination)، وهو الخئ الخيال الذي يوحّد بين الأشياء

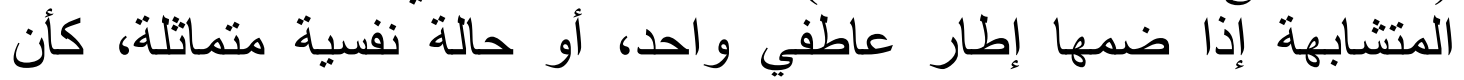

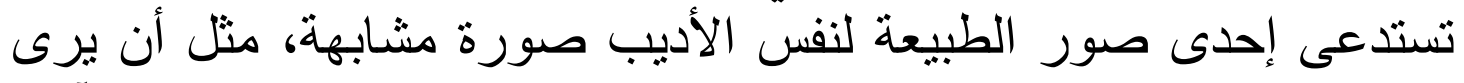

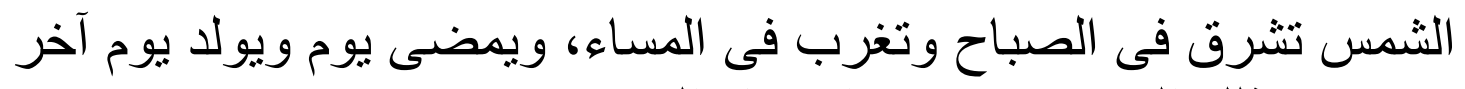
فيستدعى ذللك إلى نفسه صورة النقاح ونغاء العمر.

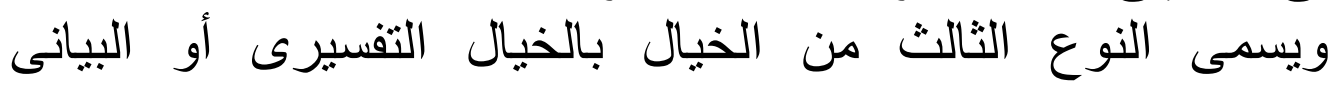

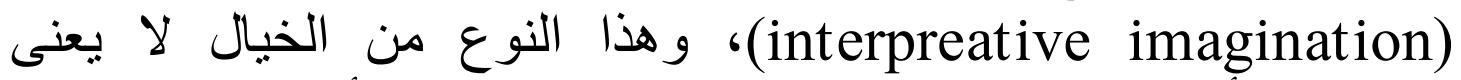

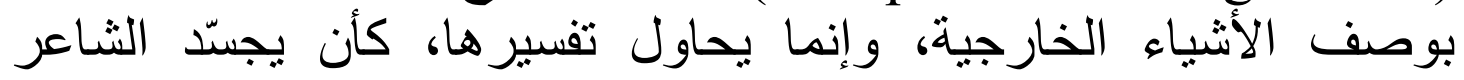
الطبيعة إنسانا، أو يمثلها فتاة حسناء، بغية تفسير جمالها مثلا. 22

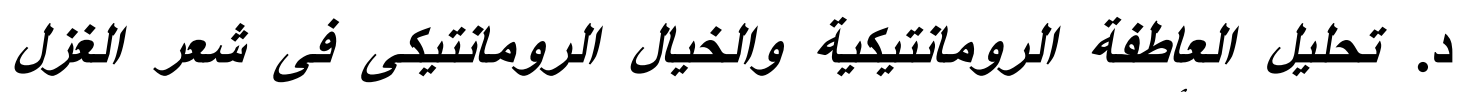

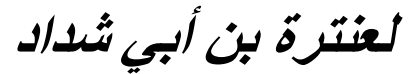

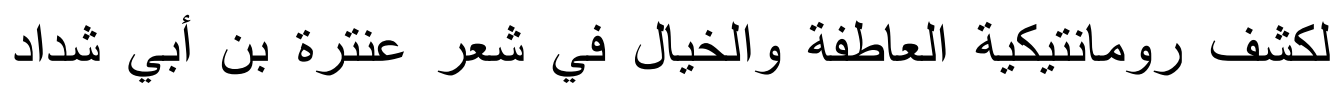
نركز البحث على قافية الدال، من بحر طويل، التي وردت في في ديوة التي شئران

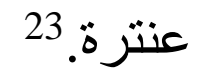
أو لا: العاطفة الرومانتيكية في شعر عنترة، وينقسم هذا النوع من العاطفة إلي العو اطف الثخصية والأليمة.

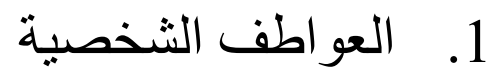

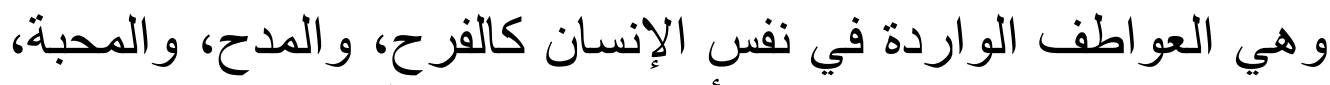

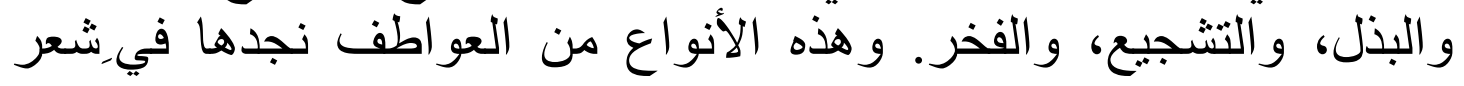

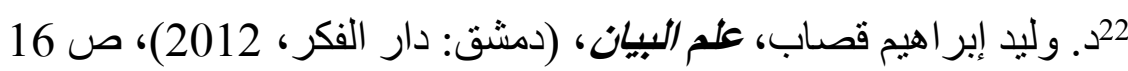

$$
\begin{aligned}
& \text { 3شرح ديوان عتترة، (بيروت_لبنان: دار الكتب العلمية، د.ت.)، ص } 59
\end{aligned}
$$


عنترة وهي آثار الحالة الخارجية24. و الخارجية هنا تحتوى على الأشياء

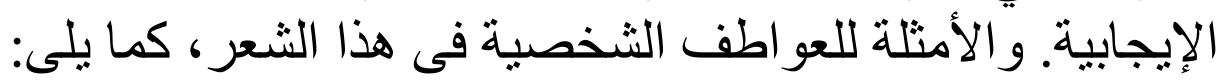

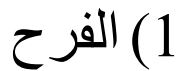

وهو السرور أو نقيض الحزن. 25 وقال ثعلب هو أن يجد في قلبه

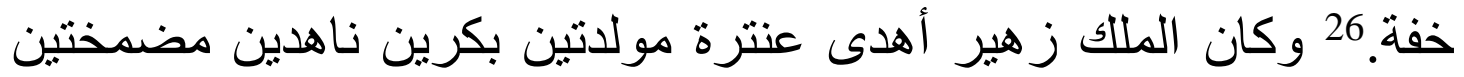

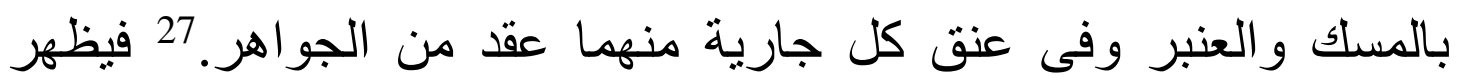

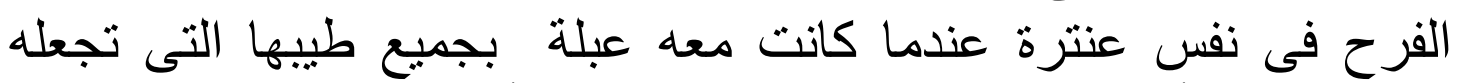

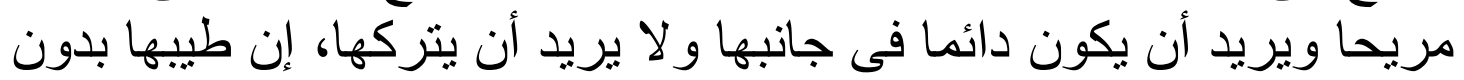

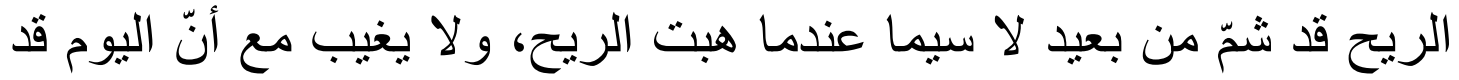

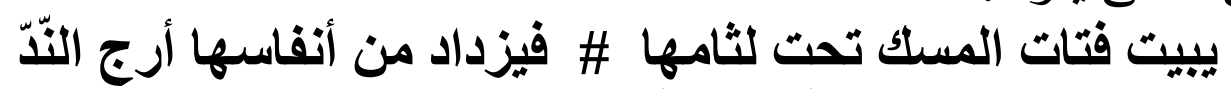

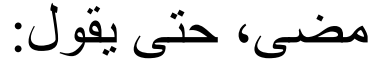

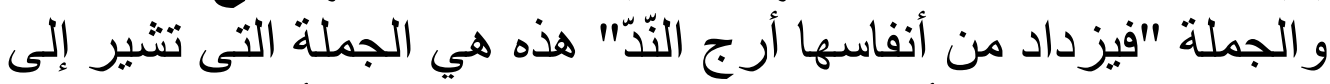

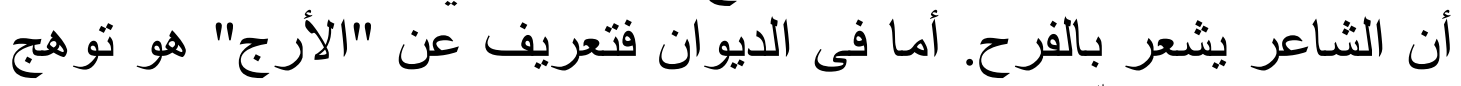

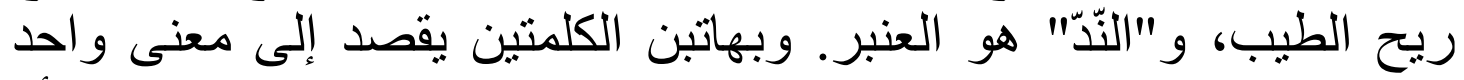

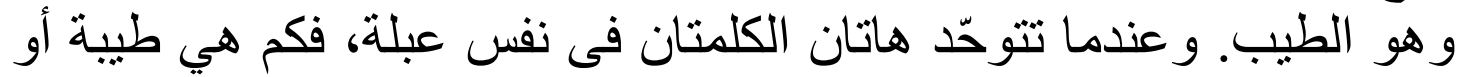

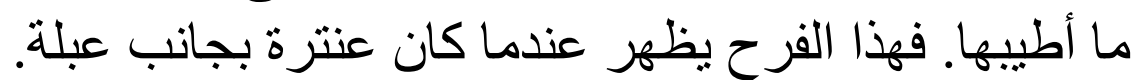

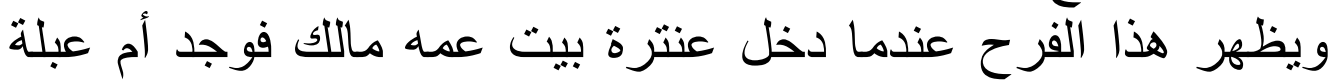

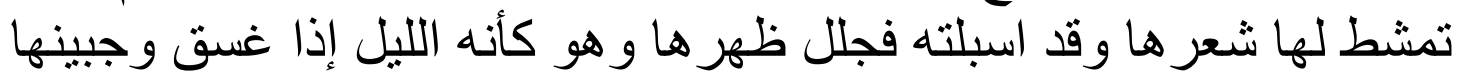

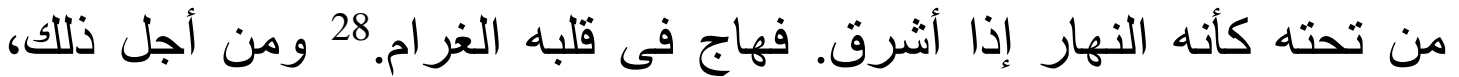

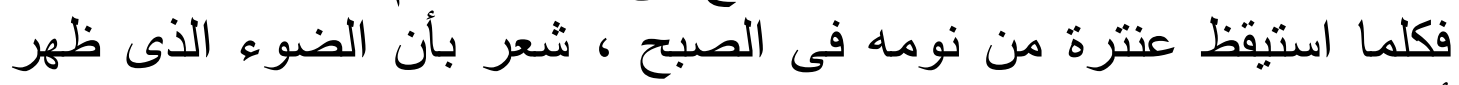

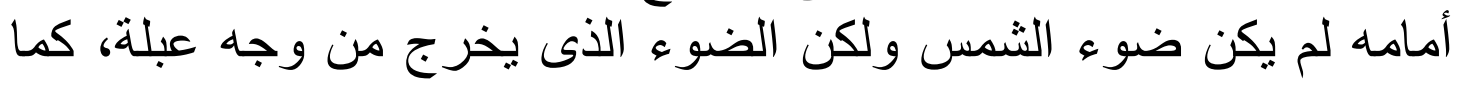

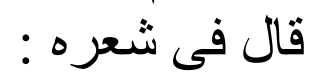

124 أحمد الثايب، أصول النق الأدبى، (القاهرة: مكتبة النهضة الدصرية، 1994)، ص $182-181$

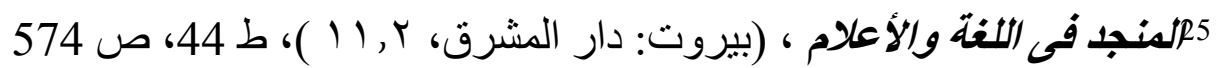

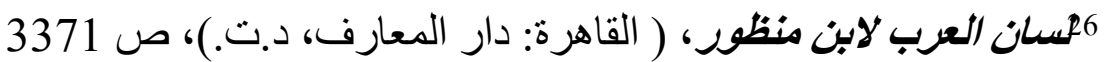
1927أنيس وكمال بكاشان، كتاب عتترة بن شداد الجزء الأول، (بيروت: الدطبعة الأدبية، 1908)، صن 65 28 أنيس وكمال بكاش،كتاب غتترة بن شداد الجزء الأول،(بيروت: المطبعة الأدبية،

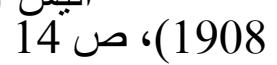


ويطلع ضوء الصبح تحت ببينها \# لفيغشاه ليل من دجى شعر ها الجعد

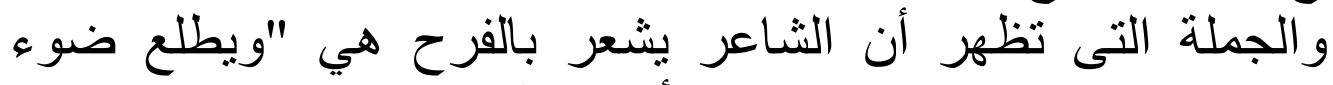

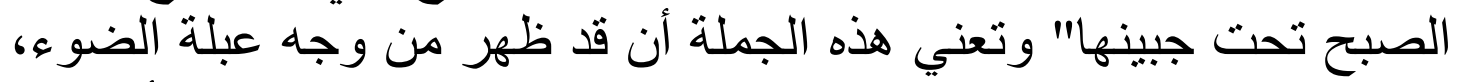

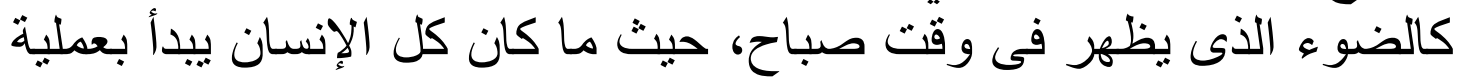

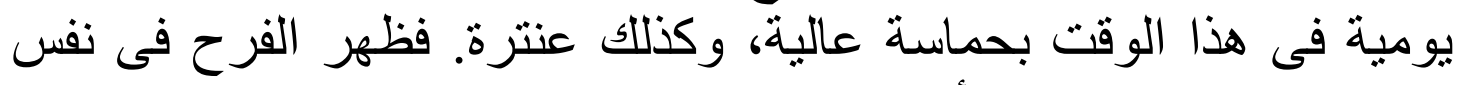
عنترة فرح شديد عندما رأى وجه الوفي عبلة.

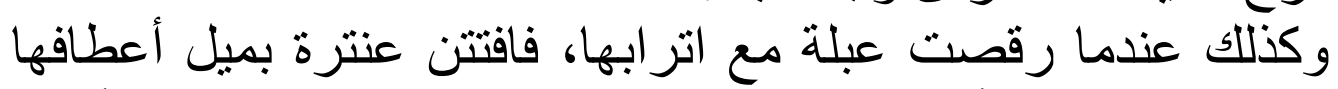

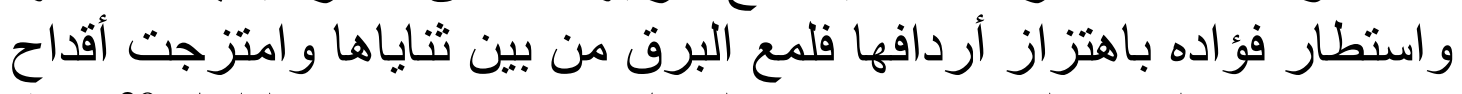

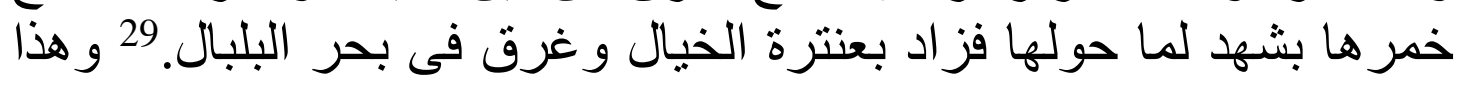

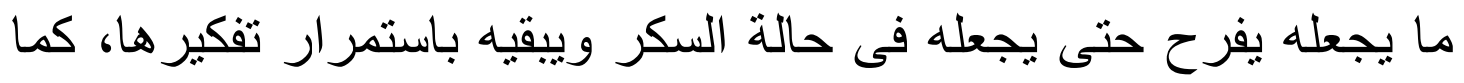
وصفها فى شعره:

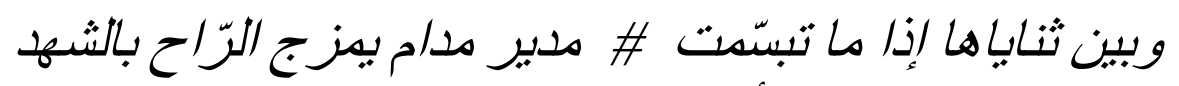

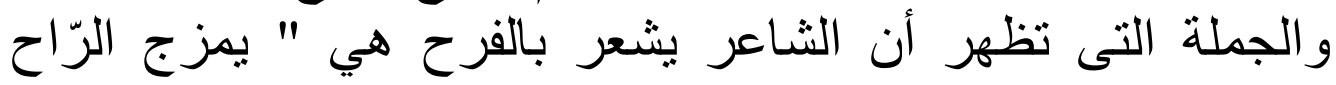

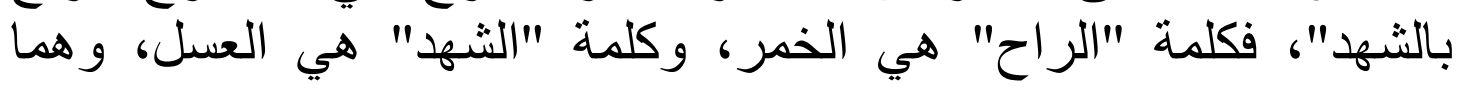

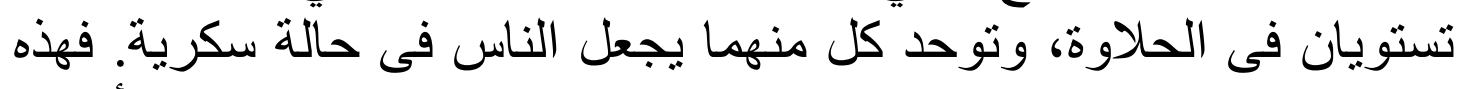

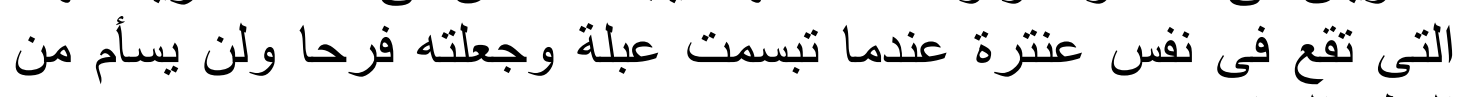

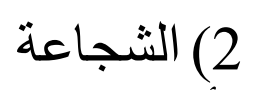

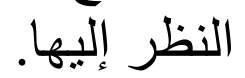

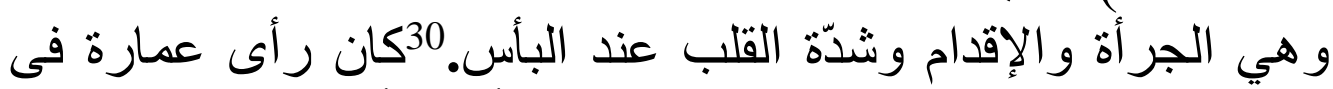

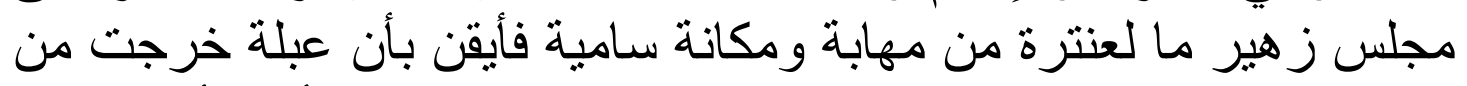

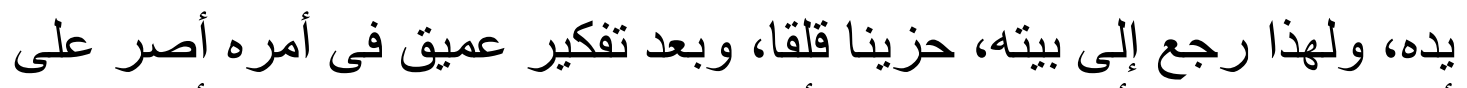

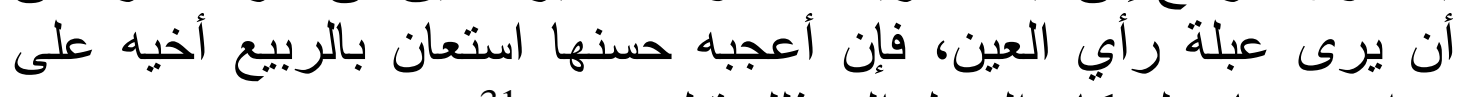
زواجه منها، ولو كان السبيل إلى ذللك قتل عنترة.

29 أنيس وكمال بكداشكتاب عنترة بن شداد الجزء الأول،(بيروت: المطبعة الأدبية، 1908)، صن أبس 21

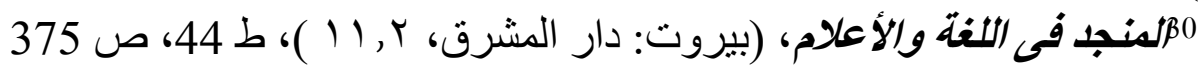

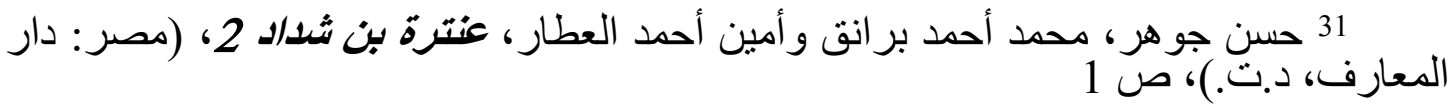




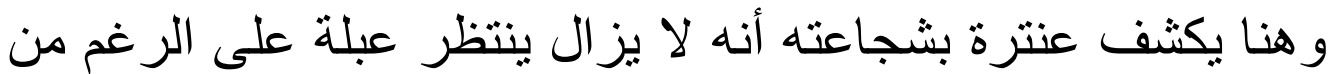

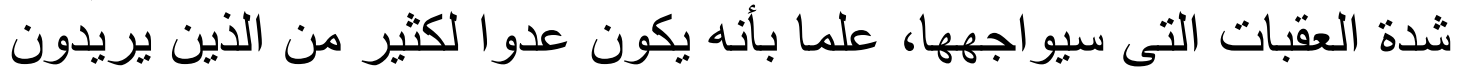

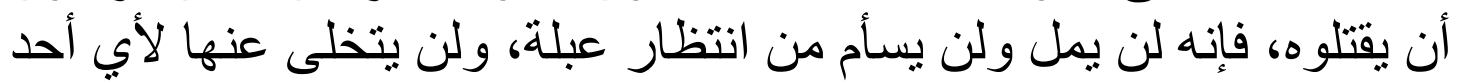
كان، كما قال فى شعره: سأحلم عن قومى ولو سفكوا دمى \# وأجرع فيك الصبر دون

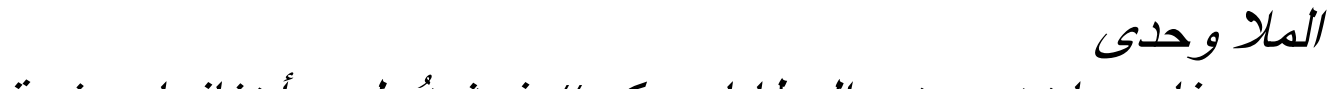
فابن عابنت عيني الدطايا وركبه\# فرشتُ لدى أخفافها صفحة الخدّ

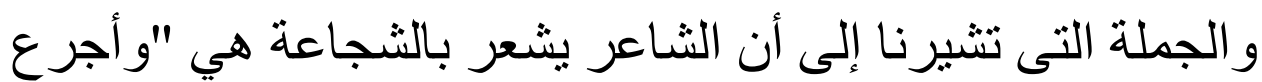

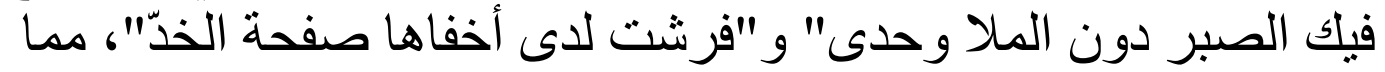

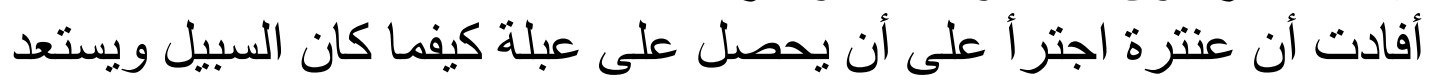
لانتظار ها طو ال عمره، وحتى أن يفرش خده لست أسلامة سفر ها.

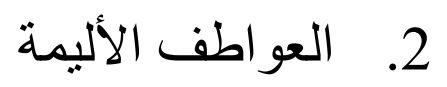

وهي العواطف فى نفس الإنسان من الحالة السلبية. وأنواعها هي:

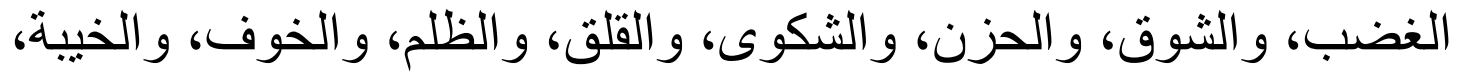

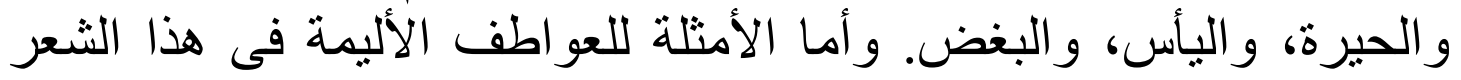

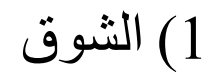

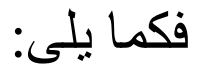

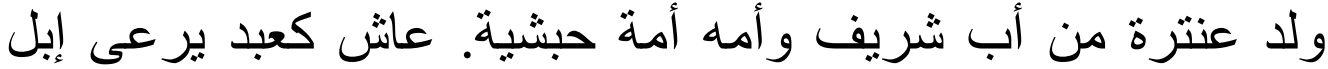

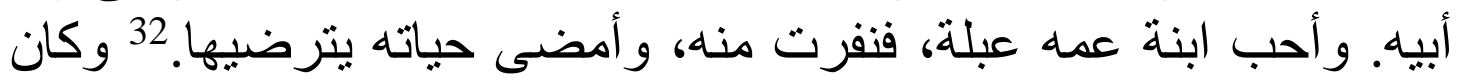

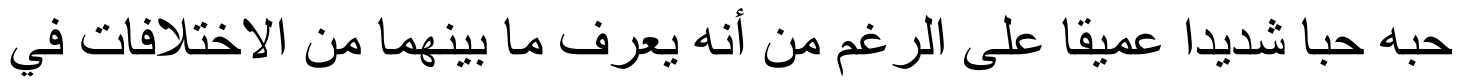

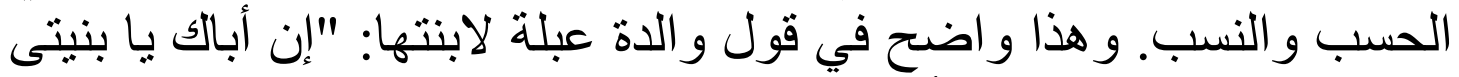

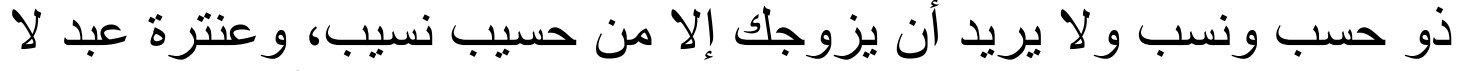
يملك إلا سيفه ولسانه".33 ولكنه يتجاهل بتلك الاختلافات لأنها كانت دائما

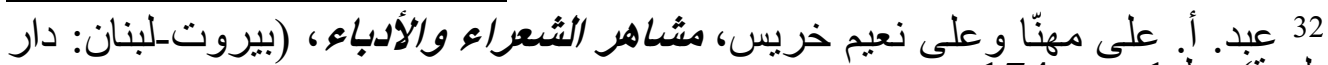
الكتب العلمية)، طن 1، صلى مثن 174 المعارف، 33 حسن جو هر، ، محمد أحمد برانق وأمين أحمد العطار، غنترة بن شداد 1، (مصر : دار 
فى ذهنه كلما وحيثما كان. وكذلك عند ذهابه مع قومه إلى اليمن حضرت

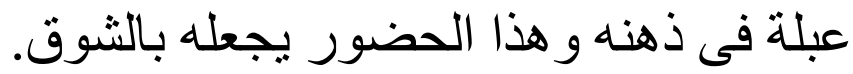

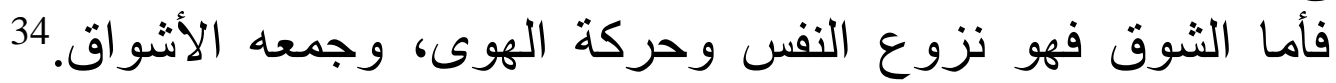

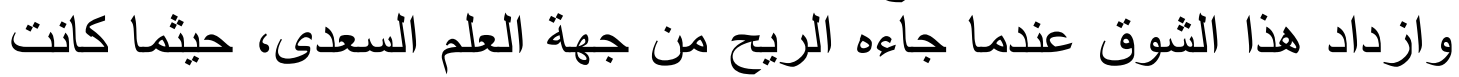

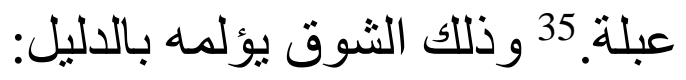

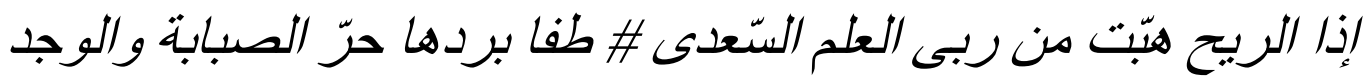

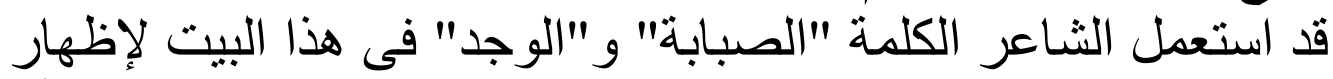

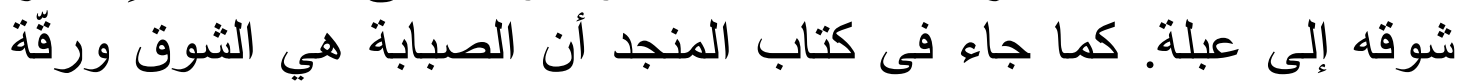

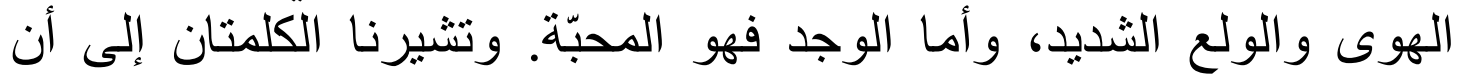
الثاعر يثتيق إلى عبلة ويحبها حبا شديدا حقيقيا ولن يغيب حيثنا كان.

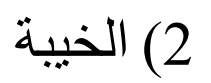

عندما اشتهرت شجاعته بين العرب كان عنترة أحسن العرب شيمة

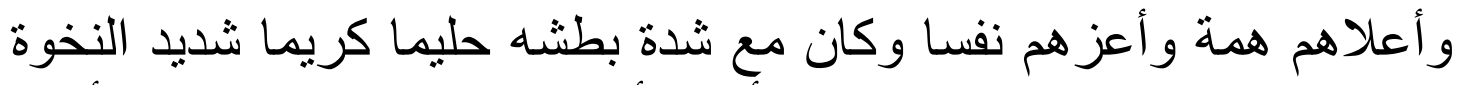

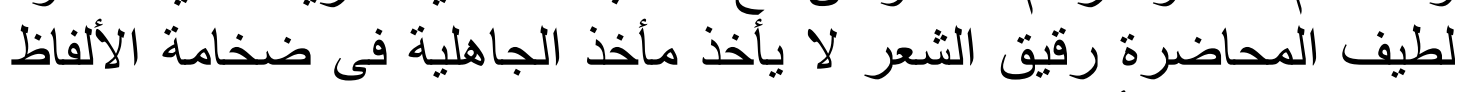

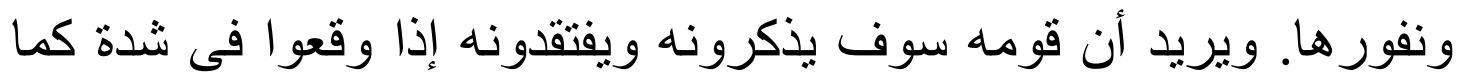

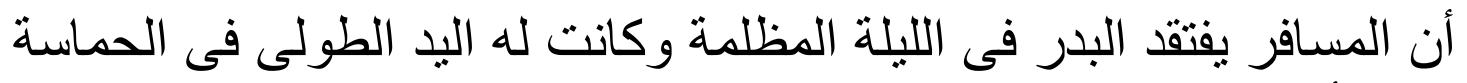

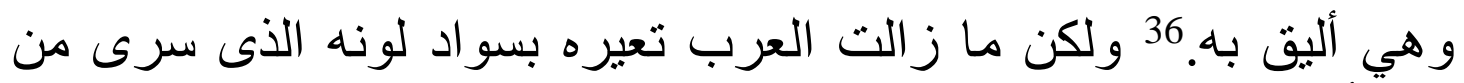

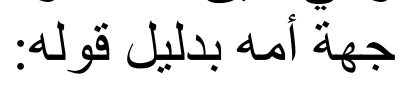

يعيبون لونى بالسواد جهالة \# \# ولو لهاه لاد سواد الليل ما طلع الفجر

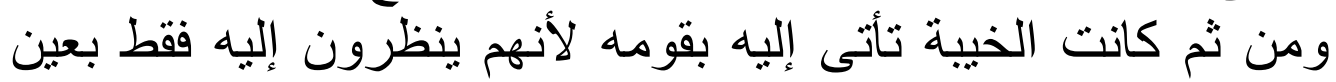

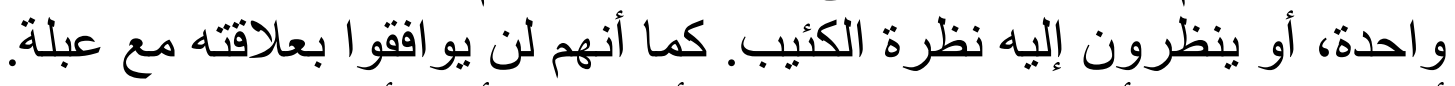

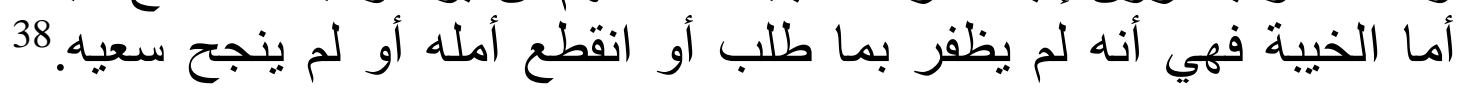

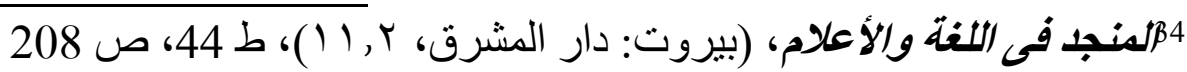

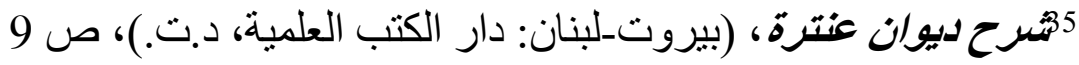

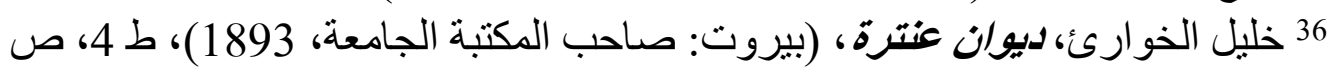

37 خليل الخوارئ، ديوان عنترة، (بيروت: صاحب المكتبة الجامعة، 1893)، ط 4، ص

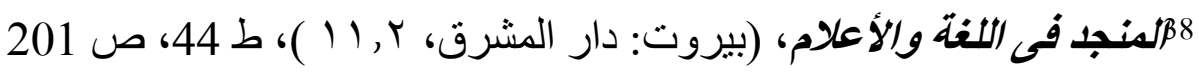


وكان العلم السعدى يذكّره بالقوم الذين هو فيهم، كما هو مفهوم من قوله فى

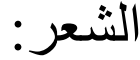

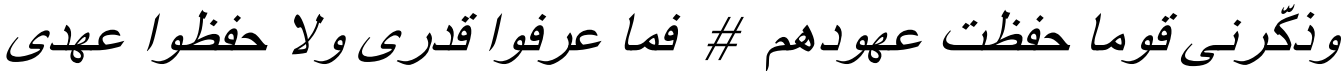

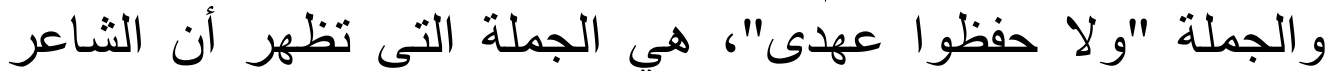

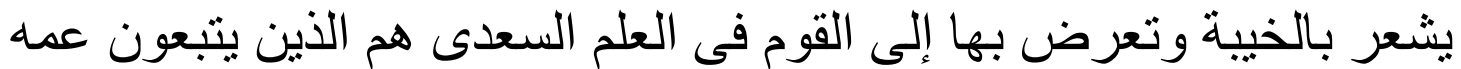

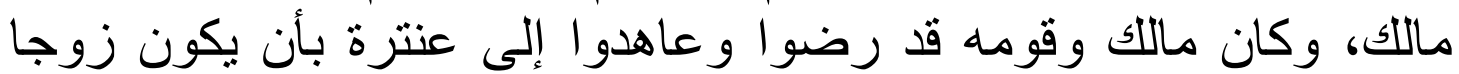
لعبلة، ولكنهم يكذبّونه وينكرونه فثنعر بالخيبة إليهر. 3) القلق

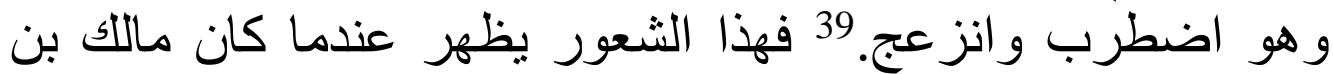

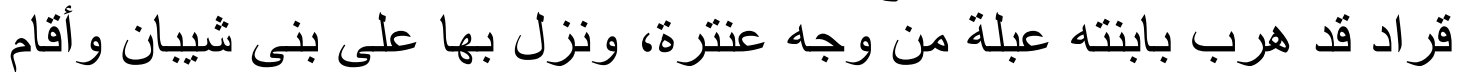

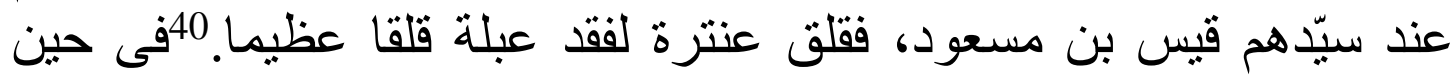

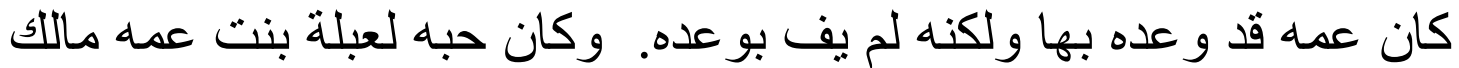

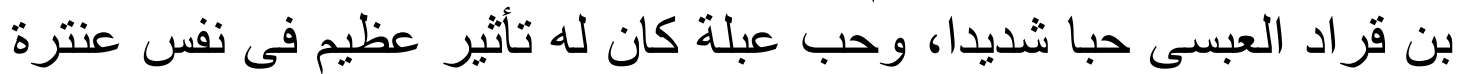

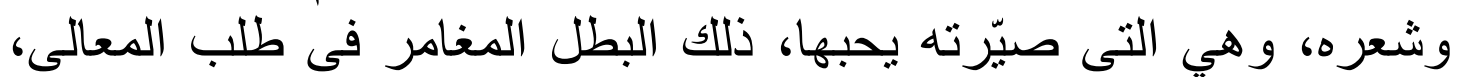

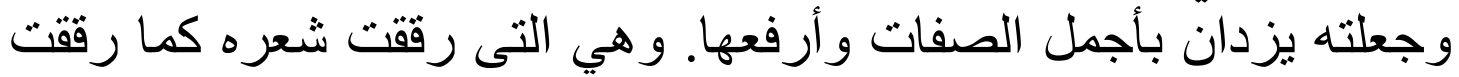

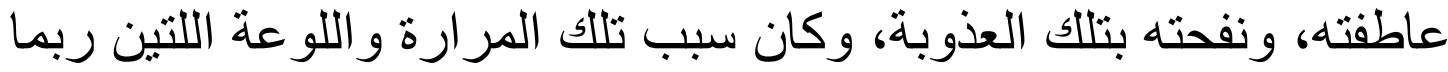

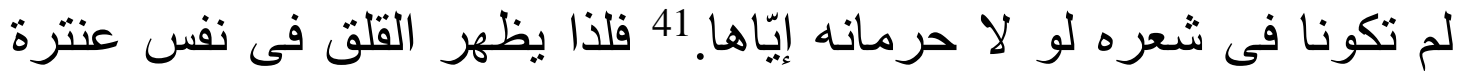

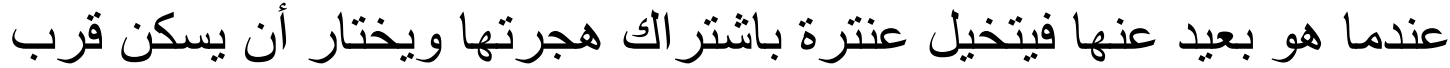

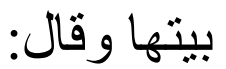

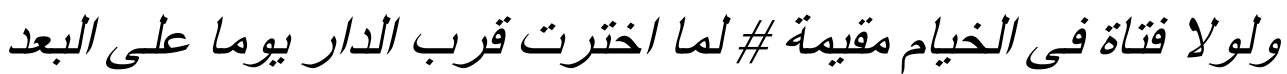

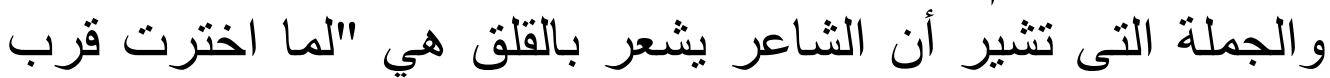

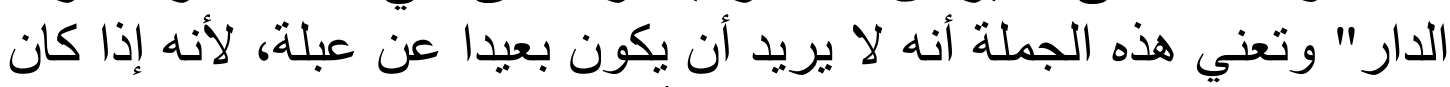

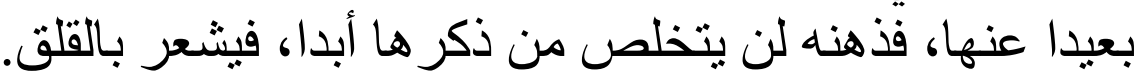

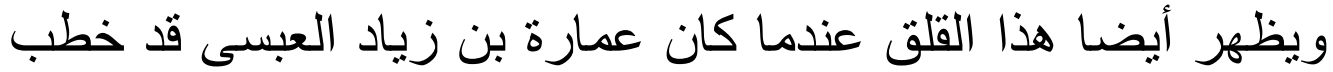
عبلة من أبيها مالك بحضور جماعة من سادات عبس، وكان زئن مالك وولده

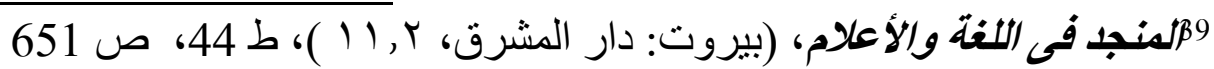

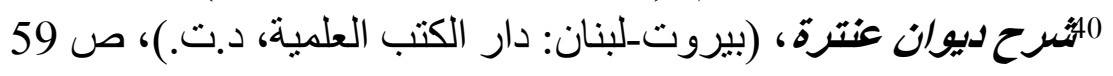

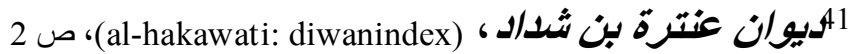


عمرو بحبّان عمارة وير غبان فى مصاهرته لغناه وشهرته، فأجاباه إلى ذلك

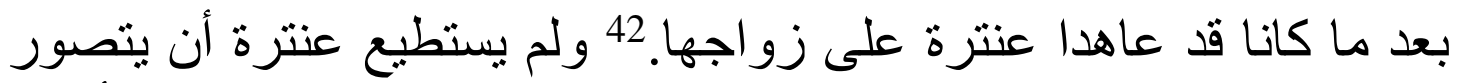

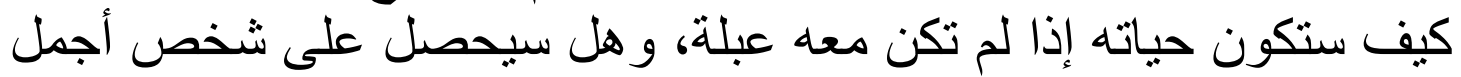

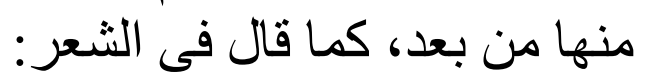

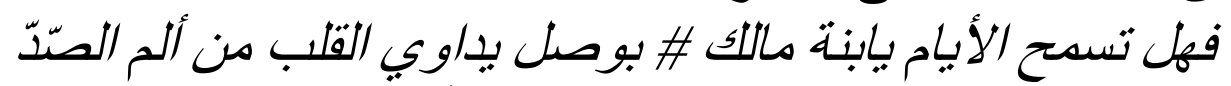

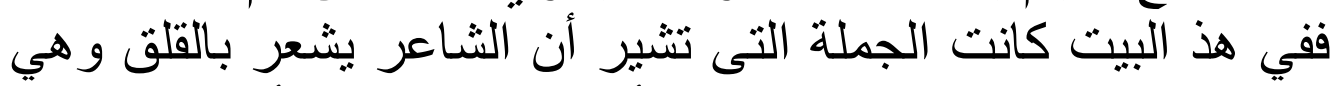

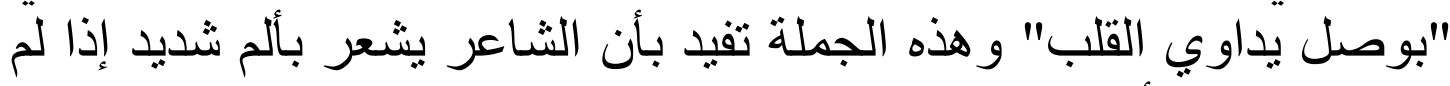

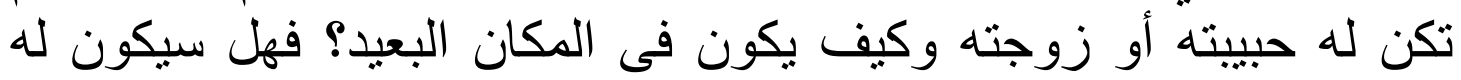

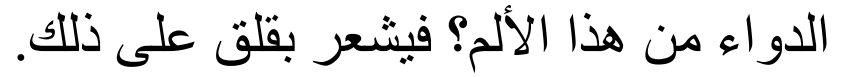

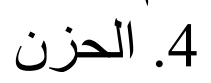

وفى الصباح خرج عنترة بإبله وخيله، وخرج أبوه و وعمّاه على أثره،

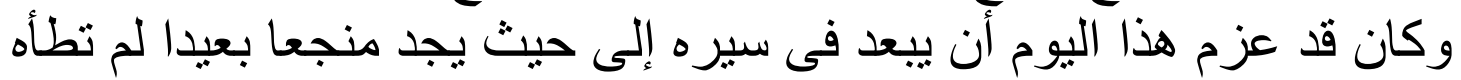

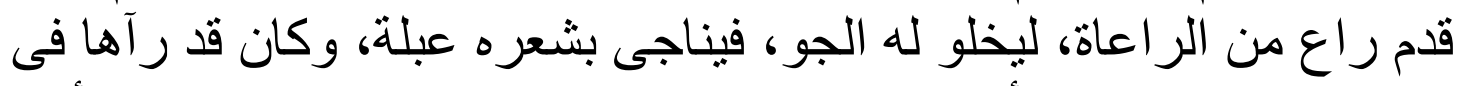

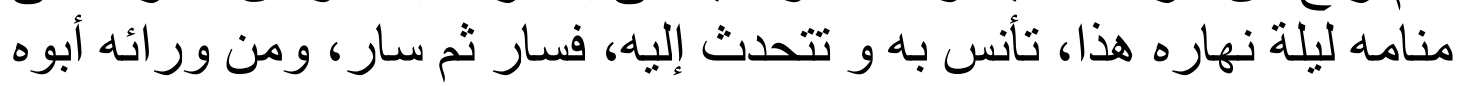

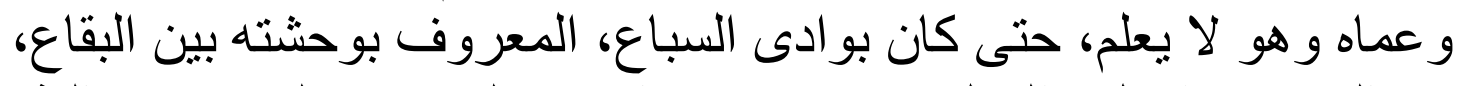

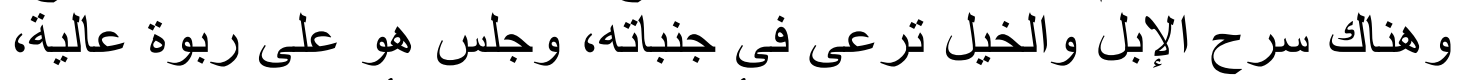
يناجى خيال عبلة.

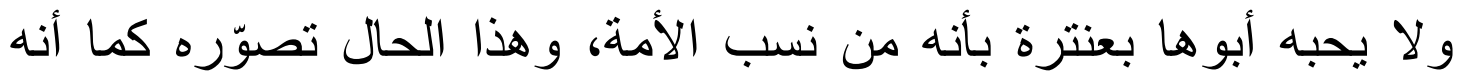

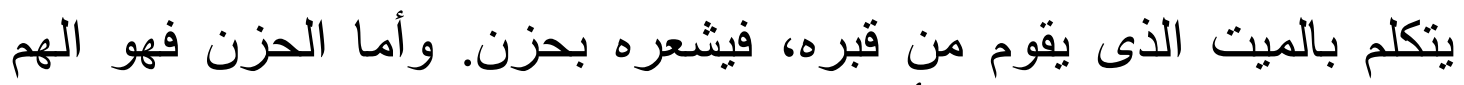

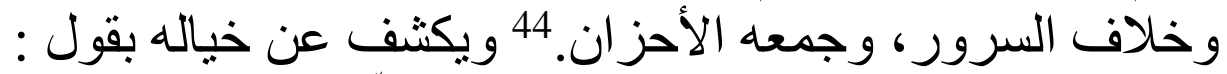

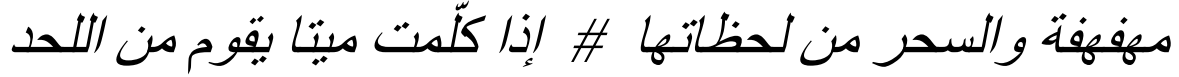

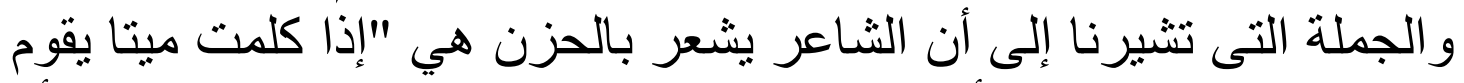

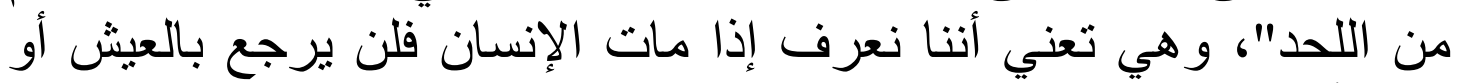
حتى أن يتحدث معنا، و هنا عبر الثاعر عن عن العكس، فكان هذا مستحيلا.

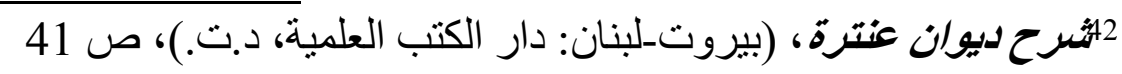

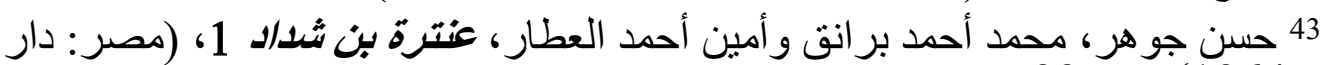

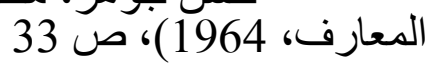

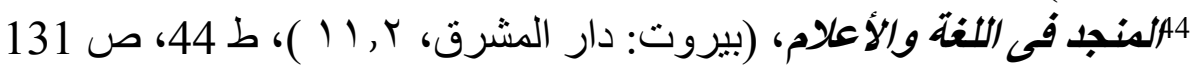


وكان هذا المستحيل يعرضها إلى أحلامه فى المنام بمقابلته مع عبلة التى التى رآها جميلة جدا، فظهر الحزن بسبب هذا المستحيل.

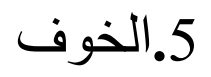

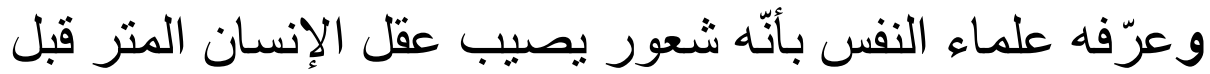

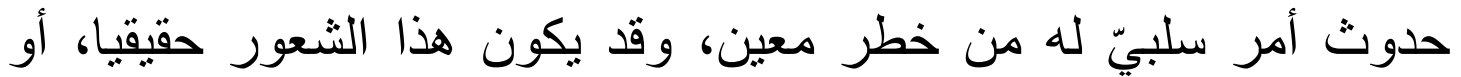

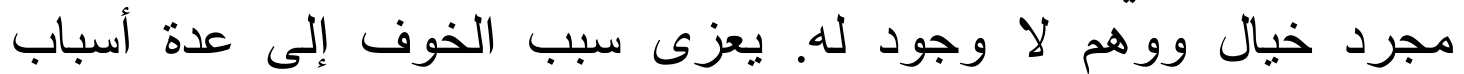

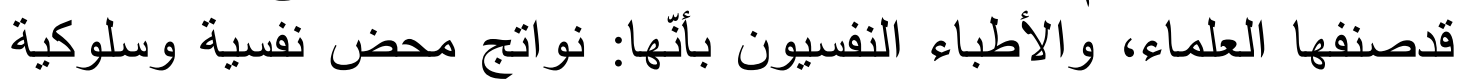

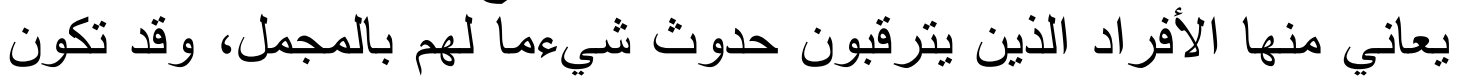

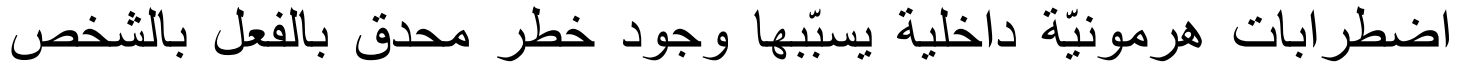

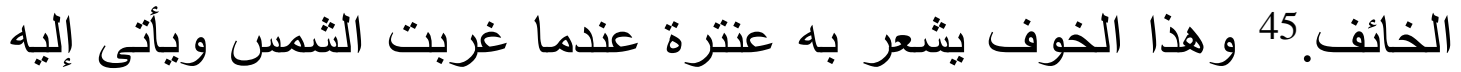

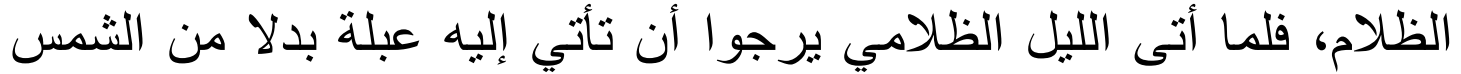

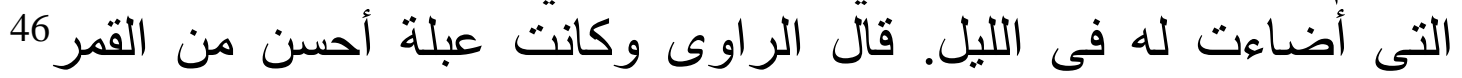

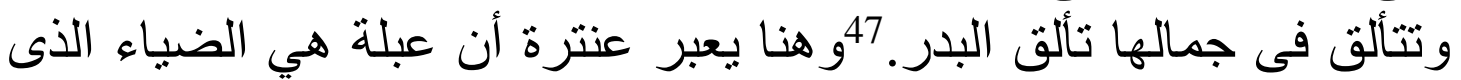

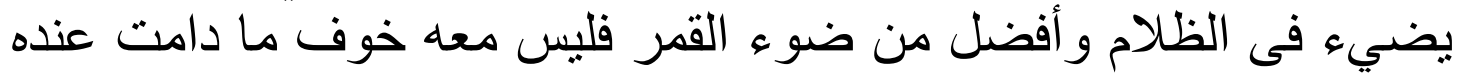

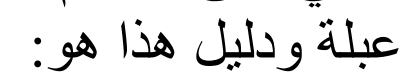

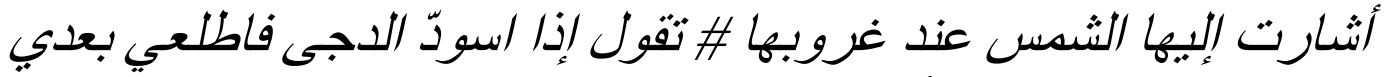

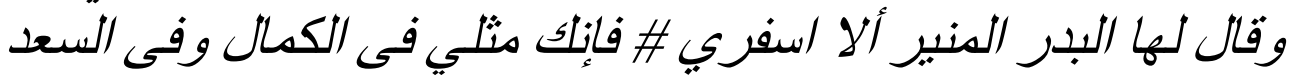

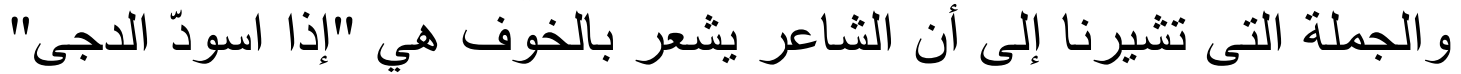

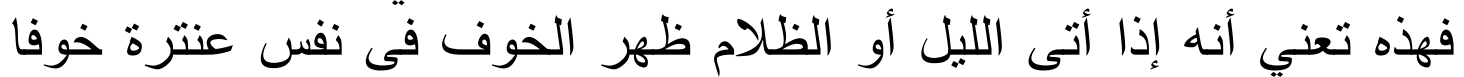

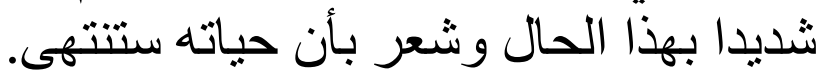

ثانيا: الخيال الرومانتيكي

\begin{tabular}{|c|c|c|c|c|}
\hline & & الحيال البيالى & & \\
\hline لوع البيان & المسبكه به & المسنبه & بياب السعر & الرجم \\
\hline البليخ & والْبّابة & الريح & 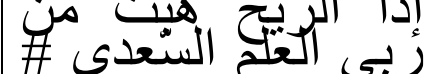 & .1 \\
\hline
\end{tabular}

45 نعريف الخوف/mawdoo3.com، تعريف الخوف، (بواسطة :مريم مساعدة ـآخر

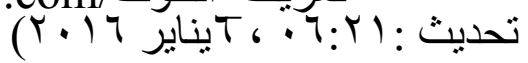
46أنيس وكمال بكداشكتاب عنترة بن شداد الجزء الأول، (بيروت: د.ن.، 1908)، ص المعارف، 47 حسن جو هر ، محمد أحمد برانق وأمين أحمد العطار، عنترة بن شداد 1، (مصر : دار 


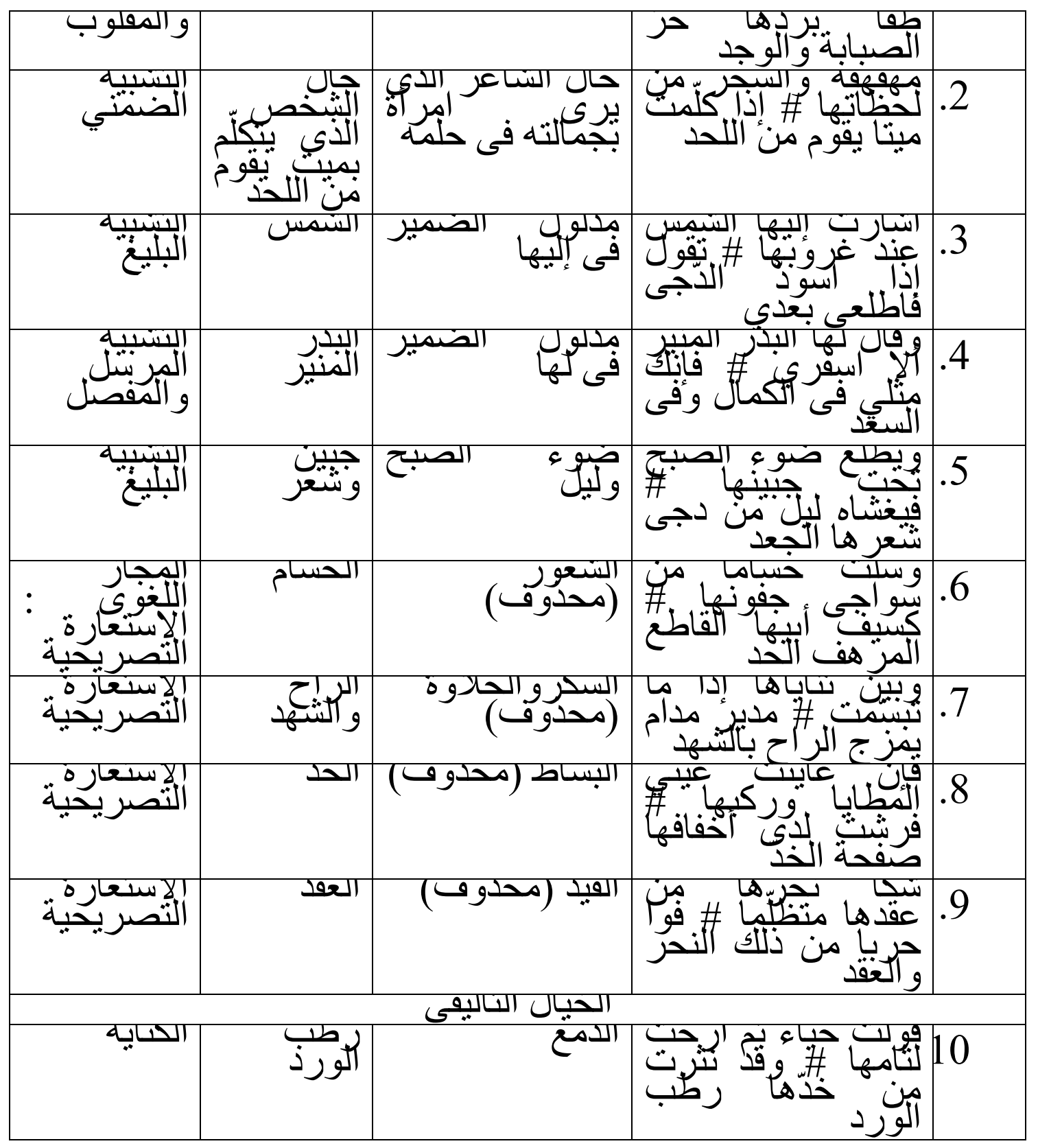

\section{ن. - مـ الخلاصة}

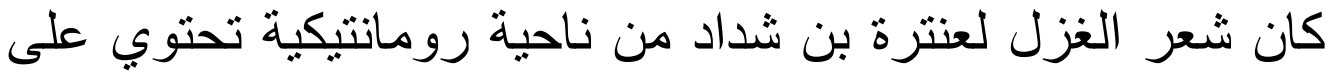

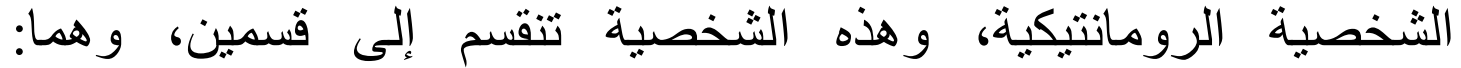
الإحساسات، والمشاعر الرومانتيكية، أوتسمى بالعاطفة و والخيال 
الرومانتيكى. والعاطفة تنقسم إلى العاطفة الثخصية والعاطفة الأليمة.

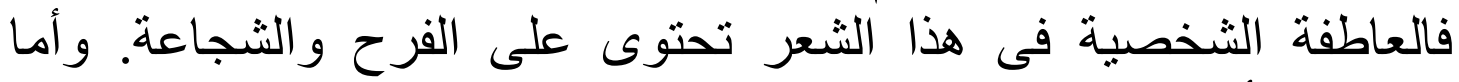

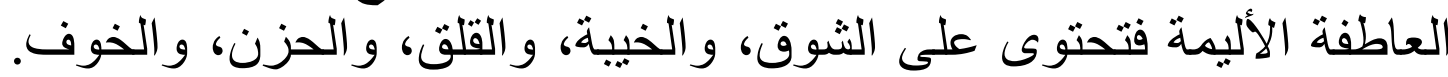

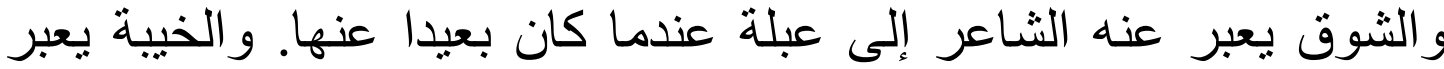

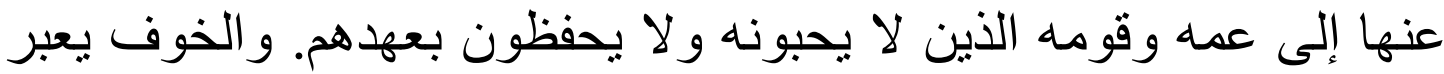

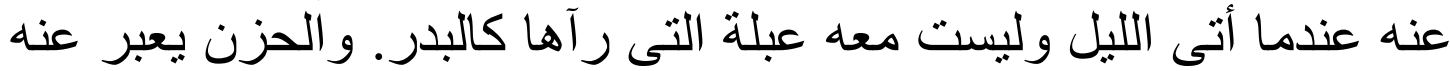

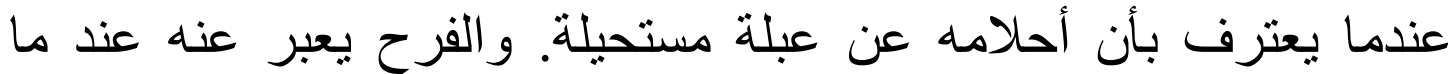

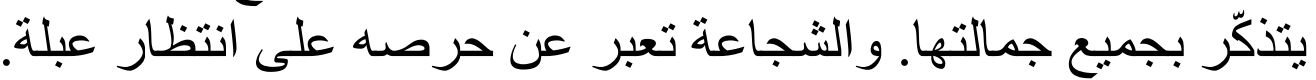

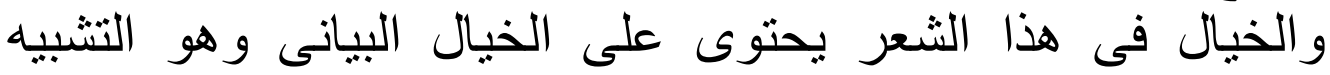

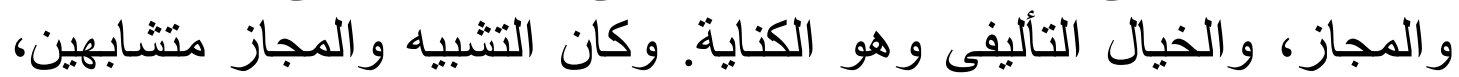

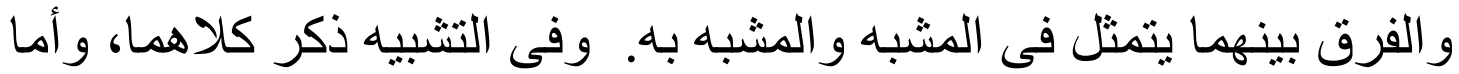

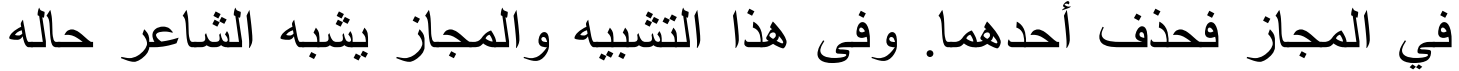

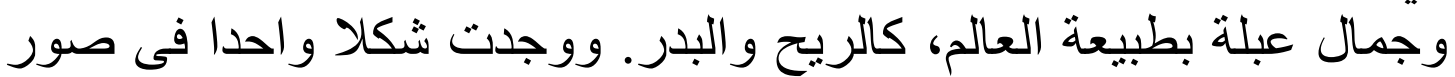

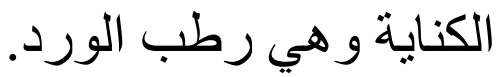

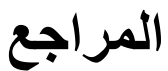

الإسكندري، أحمد، ومصطفى عنانى، الوسبط فى الأدب العربي وتاريخه،

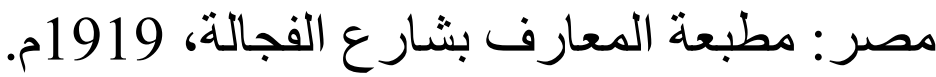

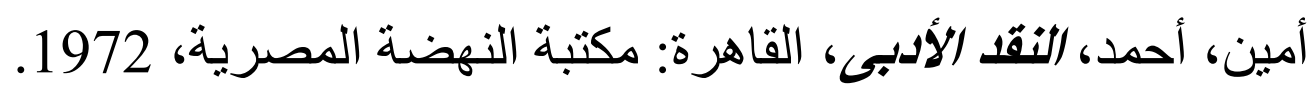
أنيس، وكمال بكداش، كتاب عنترة بن شداد الجزء الأول، بيروت، 1908.

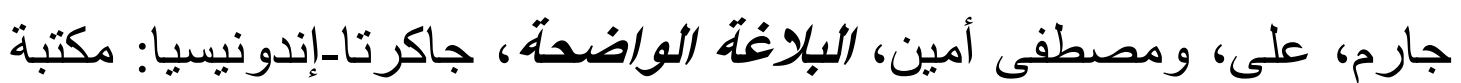

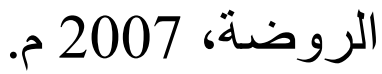

جوهر، حسن، وآخرون، عنترة بن شداد1 ، مصر: دار المعارف، 1964. 
جوهر، حسن، وآخرون، عتترة بن شداد 2، مصر: دار المعارف، د.ت.

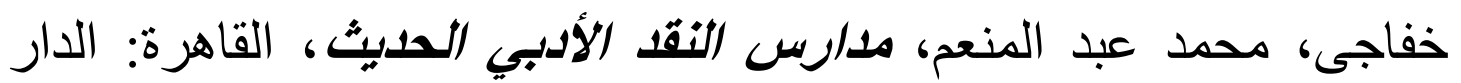

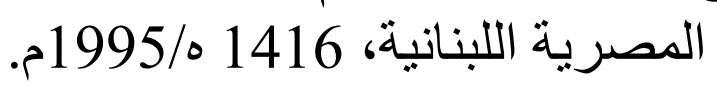

الخو ارئ، خليل، ديوان عنترة، بيروت: صاحب المكتبة الجامعة، 1893.

ديوان عنترة بن شداد، (al-hakawati: diwanindex) الثايب، أحمد، أصول النقل الأدبي، ط الثداد، 10، القاهرة: مكتبة النهضة

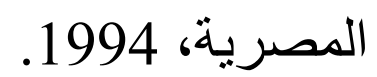

شرح ديوان عنترة، بيروت_لبنان: دار الكتب العلمية، د.ت.

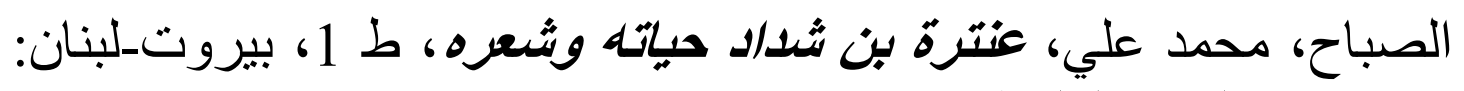

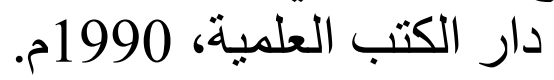

طمّاس، حمدو ، ديوان عنترة بن شد/د، ط 200، بيروت_لبنان: دار المعرفة،

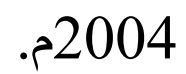

عيد، رجاء، فلسفة البلاغة بين التقنية والتظور، ط 2004، إسكندرية: منشأة

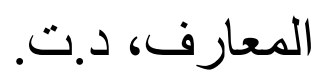

الفيصل، عبد العزيز بن محمد، الأدب العربي وتاريخه، ط د 1،المملكة

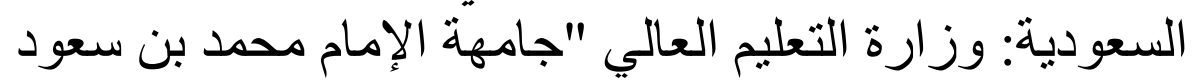

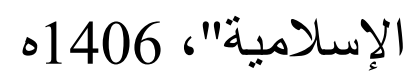

قصاب، د. وليد إبر اهيم، علم البيان، دمثقن: دار الفكر، 2012.

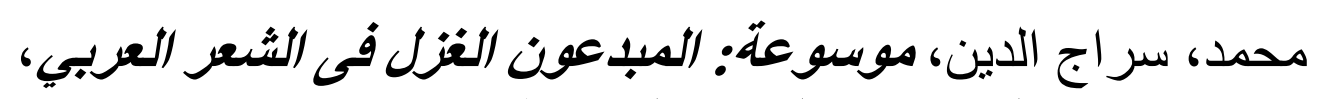

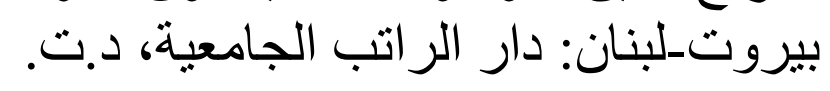

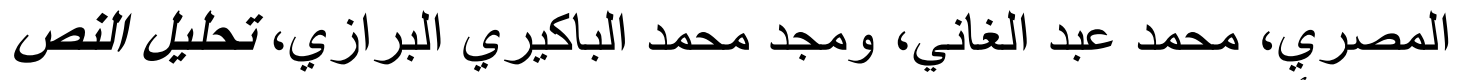
الأدبي، عمان: مؤسسة الوراق، 2002. المنجد فى اللغة والوعلام، ط 44،بيروت: دار المشرق، لأنس 2011. 


$$
\text { منظور، ابن، لسان العرب، القاهرة: دار المعارف، د.ت. }
$$

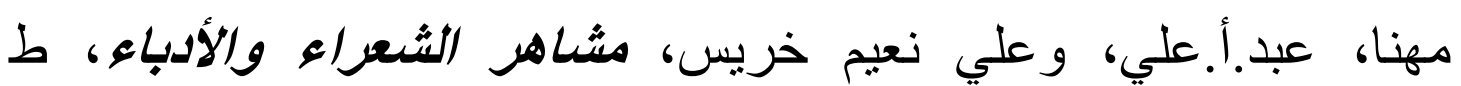
1،بيروت_لبنان: دار الكتب العلمية، 1990م.

الهاثمي، السيد أحمد، جواهر البلاغة فى الدعانسي والبيان والبلبيع، صيدا بيروت: المكتبة العصرية، د.ت.

هلال، محمد غنيمي، الروماتتيكية، القاهرة: د.ن.، د.ت. 
